\title{
A Review of the Structure-Activity Relationship of Natural and Synthetic Antimetastatic Compounds
}

\author{
Su Ki Liew ${ }^{1}$, Sharan Malagobadan ${ }^{1,2}$, Norhafiza M. Arshad ${ }^{2}$ and Noor Hasima Nagoor $1,2, *$ (1) \\ 1 Institute of Biological Science (Genetics and Molecular Biology), Faculty of Science, University of Malaya, \\ 50603 Kuala Lumpur, Malaysia \\ 2 Centre for Research in Biotechnology for Agriculture (CEBAR), University of Malaya, \\ 50603 Kuala Lumpur, Malaysia \\ * Correspondence: hasima@um.edu.my
}

Received: 30 August 2019; Accepted: 8 October 2019; Published: 14 January 2020

\begin{abstract}
There are innumerable anticancer compounds derived from either natural or synthetic origins. Many of these compounds have been further developed through structural modifications to not only inhibit cancer cell growth but also to exert an antimetastatic effect. This is achieved by attaching different substituents to generate different structure-activity relationships. This review highlights the effectiveness of different functional groups known to have antimigration and antiproliferation activities, such as fluoro, methoxy, methyl, amino, hydroxy, nitro, bromo, chloro, methylamino, ethoxy, carbonyl, iodo, and trifluoromethyl groups. Additionally, the positioning of these functional groups plays an important role in their anticancer activities, which was evident in one of our studies comparing analogues of a natural compound. Thus, this review suggests future recommendations for the design and development of improved anticancer drugs with higher efficacy.
\end{abstract}

Keywords: substituent; synthesis; antimetastasis; structure-activity relationships; biotechnology

\section{Introduction}

Cancer, a chronic disease, ranks in the top three leading cause of death worldwide [1]. In the development of cancer treatment, natural and synthetic compounds have both been explored for their cytotoxicity [2]. Many Food and Drug Administration (FDA)-approved anticancer drugs, such as paclitaxel, vincristine, vinblastine, and bortezomib, are derivates of natural compounds sourced from various plants [3-5]. Consequently, more natural compounds have been discovered and reported for their anticancer activity, such as the epipodophyllotoxin derivatives, maytansine, bruceantin, thalicarpine, camptothecin, and lapachol [6]. Furthermore, modification of these compounds has proven to be more effective in minimising side effects and targeting other oncogenic phenotypes, such as metastasis. An important hallmark of cancer progression, metastasis is a complex cascade of events that involves separation of cancer cells from the primary tumour followed by intravasation, extravasation and the eventual formation of secondary tumours [7]. Due to the high mortality rate in cancer caused by metastasis [8], the development of antimetastatic drugs has become a new aim in modern cancer therapy.

While a number of literature reviews have addressed the structure-activity relationship (SAR) of anticancer agents in terms of inhibition of cancer cell growth, SAR on targeting the metastatic process has not received as much attention. Therefore, the aim of this review is to fill the gap in SAR analysis of different functional groups in natural product and synthetic analogues with their antimetastatic and antiproliferative properties. In this paper, the functional groups reviewed are the fluoro, methoxy, methyl, amino, hydroxy, nitro, bromo, chloro, methylamino, ethoxy, carbonyl, iodo and trifluoromethyl groups. They are classified as either effective or weak in antimigration and antiproliferation effects. 
Furthermore, the position of the functional groups may also affect the effectiveness of the substituent in blocking the migration and growth of cancer cells.

\section{Effective Functional Groups, Their Position and Antimigration Effects}

\subsection{Fluoro (F) Group}

Abid et al. [9] investigated the antimetastatic activity of isocoumarin analogue using collagen type I invasion assay. Among the analogues, compound 3-(3',4'-difluorophenyl) isocoumarin 1 was found to be the most potent in exerting antimetastatic activity compared to the control. SAR study (Figure 1) concluded the fluoro groups on the meta and para positions of the phenyl ring at C-3 and the double bond of the isocoumarin nucleus increases the antimetastatic effect.

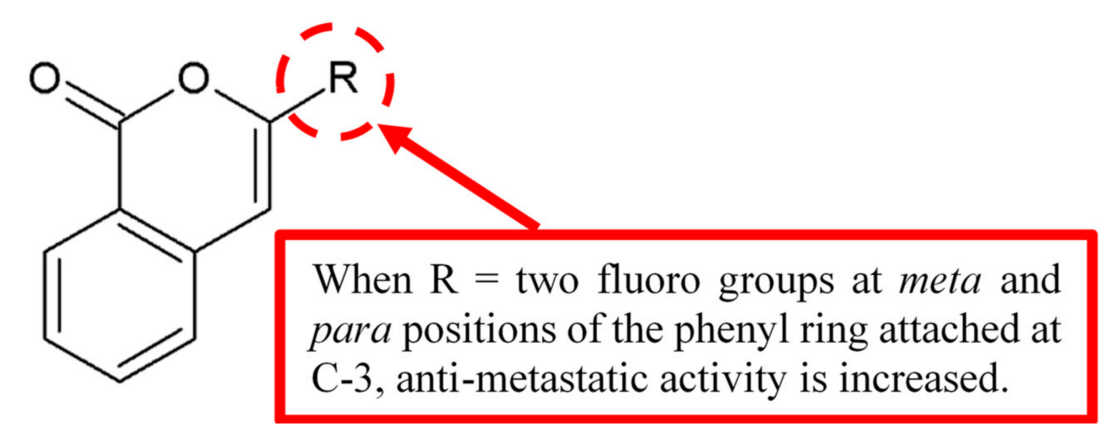

Figure 1. Structure-activity relationship (SAR) study of isocoumarin derivative 1.

A series of brartemicin analogues were synthesised by Jiang et al. [10]. These analogues were the product of Mitsunobu coupling of the secondary hydroxyls benzyl protected $\alpha, \alpha$-D-trehalose with benzoic acid derivatives and functional group modification and deprotection. Anti-invasion activity of these synthetic analogues was assessed on colon cancer 26-L5 cells (Figure 2). Among these compounds, the 2,6-difluoro- substituted analogue $3 \mathrm{~h}$ maintained the anti-invasive activities (Table 1 ). However, the fluoro group at the 4-position of the benzoic acid ring coupled with the 3-methoxy group lost their anti-invasive ability, indicating that the activity of fluoro group is reduced during coupling with the functionally weak methoxy group.

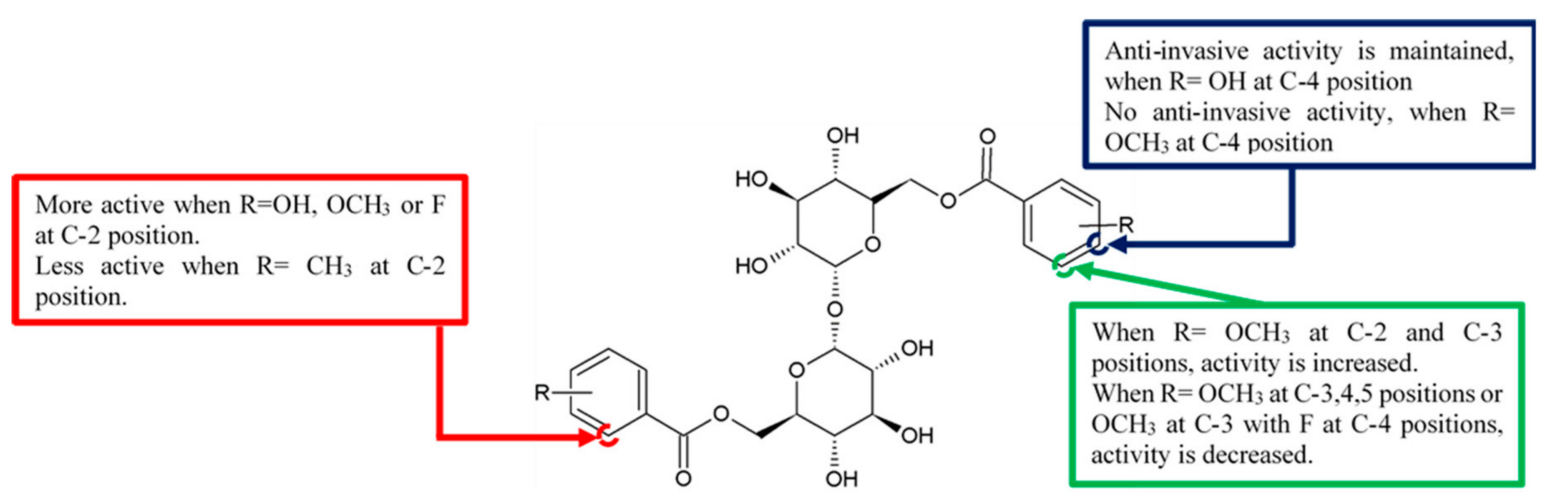

Figure 2. SAR study of brartemicin derivatives. 
Table 1. SAR study of brartemicin derivatives.

\begin{tabular}{|c|c|c|}
\hline \multirow{2}{*}{ Compounds } & \multirow{2}{*}{$\mathbf{R}$} & $\mathrm{IC}_{50}(\mu \mathrm{g} / \mathrm{mL})$ \\
\hline & & Anti-Invasive Activity In Vitro \\
\hline Brartemicin, 2 & $2,4-(\mathrm{OH})_{2}-6-\mathrm{CH}_{3}$ & 0.25 \\
\hline $3 a$ & $2-\mathrm{OCH}_{3}$ & 1.0 \\
\hline $3 b$ & $2-\mathrm{CH}_{3}$ & NA \\
\hline $3 c$ & $4-\mathrm{OCH}_{3}$ & NA \\
\hline $3 d$ & $4-\mathrm{OH}$ & 1.0 \\
\hline $3 e$ & $2,3-\left(\mathrm{OCH}_{3}\right)_{2}$ & 0.10 \\
\hline $3 f$ & $3,4,5-\left(\mathrm{OCH}_{3}\right)_{3}$ & NA \\
\hline $3 g$ & $3-\mathrm{OCH}_{3}-4-\mathrm{F}$ & NA \\
\hline $3 \mathrm{~h}$ & $2,6-\mathrm{F}_{2}$ & 1.0 \\
\hline 4 & $2-\mathrm{OH}$ & $<1.0$ \\
\hline 5 & $2,3-(\mathrm{OH})_{2}$ & $<1.0$ \\
\hline
\end{tabular}

Focal adhesion kinase (FAK) is one of the most common intracellular kinases that regulate signalling pathways associated with cellular migration, proliferation, and survival [11], making it an important target in developing anticancer drugs. To produce better FAK inhibitors, Zhang and his team [12] designed and synthesised a series of new 1,3,4-oxadiazole derivatives possessing benzotriazole moiety (Figure 3). Among the analogues, fluoro-substituted compound 6 displayed the best FAK inhibitory activity and performed better than the reference drug, cisplatin (Table 2). Moreover, analysis of the positions of fluoro substituent in the compounds revealed that the ortho-substituted compound 6 has better inhibitory activity compared to the meta- substituted compound $\mathbf{8}$ and para-substituted compound $\mathbf{1 0 .}$

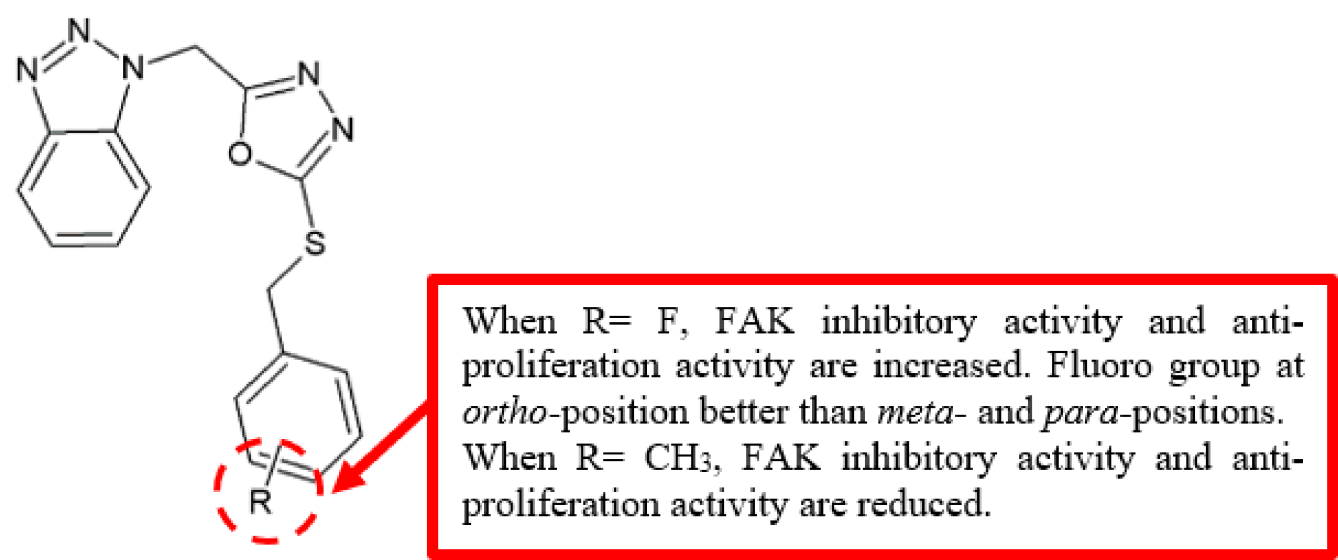

Figure 3. SAR study of 1,3,4-oxadiazole derivatives.

Table 2. SAR study of 1,3,4-oxadiazole derivatives.

\begin{tabular}{ccccc}
\hline \multirow{2}{*}{ Compounds } & $\mathbf{R}$ & \multicolumn{2}{c}{ Anti-Proliferation Activity $\mathbf{( I C}_{\mathbf{5 0}, \boldsymbol{\mu g} / \mathbf{m L})}$} & $\begin{array}{c}\text { FAK Inhibitory } \\
\text { Activity }\left(\mathbf{I C}_{\mathbf{5 0}}, \boldsymbol{\mu M}\right)\end{array}$ \\
\cline { 3 - 4 } & & $\mathbf{M C F}-\mathbf{7}$ & $\mathbf{H T 2 9}$ & $1.2 \pm 0.3$ \\
$\mathbf{6}$ & $2-\mathrm{F}$ & 5.68 & 10.21 & $12.1 \pm 1.3$ \\
$\mathbf{7}$ & $2-\mathrm{CH}_{3}$ & 18.89 & 26.81 & $7.1 \pm 0.3$ \\
$\mathbf{8}$ & $3-\mathrm{F}$ & 8.25 & 15.47 & $15.8 \pm 1.1$ \\
$\mathbf{9}$ & $3-\mathrm{CH}_{3}$ & 28.92 & 38.50 & $9.1 \pm 0.5$ \\
$\mathbf{1 0}$ & $4-\mathrm{F}$ & 8.70 & 17.62 & $33.8 \pm 1.4$ \\
$\mathbf{1 1}$ & $4-\mathrm{CH}_{3}$ & 30.23 & 42.30 & $8.6 \pm 0.2$ \\
\hline
\end{tabular}


Cathepsins, the cysteine proteases involved in the progression of various human cancers, have been shown to be promising therapeutic targets in cancer treatment [13]. For example, inhibition of one of its members, cathepsin L, reduced cancer cell invasion and migration [14]. Benzoylbenzophenone thiosemicarbazone analogues were synthesised and tested as potential cathepsin L inhibitors [15]. Among the derivatives (Figure 4), compound 12 (3-benzoylbenzophenone thiosemicarbazone) was able to inhibit the activity of cathepsin L significantly at a half maximal inhibitory concentration $\left(\mathrm{IC}_{50}\right)$ value of $9.9 \mathrm{nM}$ (Table 3). Besides, among the para substituted analogues, analogue $\mathbf{1 3}$ showed significantly high anti-cathepsin L activity similar to the unsubstituted analogue 12. Moreover, 1,3-bis(2-fluorobenzoyl)-5-bromobenzene thiosemicarbazone 18 showed higher inhibition of cathepsin $\mathrm{L}$ with an $\mathrm{IC}_{50}$ value of $8.1 \mathrm{nM}$. Once again, the findings showed that the attachment of fluoro substituents improved antimigration activity.

When $\mathrm{R}_{1}=\mathrm{F}, \mathrm{R}_{3}=\mathrm{F}$ and $\mathrm{R}_{4}=\mathrm{Br}$, exhibited increased cathepsin L inhibitory activity.

When $\mathrm{R}_{1}=\mathrm{OCH}_{3}$ or $\mathrm{OH}$ and $\mathrm{R}_{1}$,

$\mathrm{R}_{2}, \mathrm{R}_{4}=\mathrm{Br}$ activity is reduced.

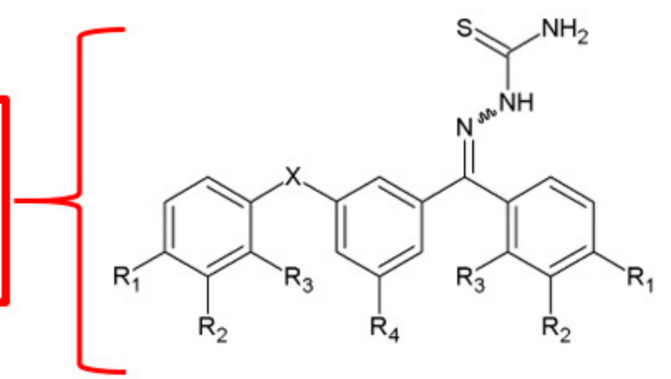

Figure 4. SAR study of benzoylbenzophenone thiosemicarbazone derivatives.

Table 3. SAR study of benzoylbenzophenone thiosemicarbazone derivatives.

\begin{tabular}{ccccccc}
\hline Compounds & $\mathbf{R}_{\mathbf{1}}$ & $\mathbf{R}_{\mathbf{2}}$ & $\mathbf{R}_{\mathbf{3}}$ & $\mathbf{R}_{\mathbf{4}}$ & $\mathbf{X}$ & $\begin{array}{c}\text { Cathepsin L Inhibitory } \\
\left.\text { Activity (IC } \mathbf{5 0}_{\mathbf{5 0}} \mathbf{n} \mathbf{\text { nM}}\right)\end{array}$ \\
\hline $\mathbf{1 2}$ & $\mathrm{H}$ & $\mathrm{H}$ & $\mathrm{H}$ & $\mathrm{H}$ & $\mathrm{C}=\mathrm{O}$ & 9.9 \\
$\mathbf{1 3}$ & $\mathrm{F}$ & $\mathrm{H}$ & $\mathrm{H}$ & $\mathrm{H}$ & $\mathrm{C}=\mathrm{O}$ & 14.4 \\
$\mathbf{1 4}$ & $\mathrm{Br}$ & $\mathrm{H}$ & $\mathrm{H}$ & $\mathrm{H}$ & $\mathrm{C}=\mathrm{NHHC}(\mathrm{S}) \mathrm{NH}_{2}$ & $>10,000$ \\
$\mathbf{1 5}$ & $\mathrm{OCH}_{3}$ & $\mathrm{H}$ & $\mathrm{H}$ & $\mathrm{H}$ & $\mathrm{C}=\mathrm{O}$ & 5117 \\
$\mathbf{1 6}$ & $\mathrm{OH}$ & $\mathrm{H}$ & $\mathrm{H}$ & $\mathrm{H}$ & $\mathrm{C}=\mathrm{O}$ & 340 \\
$\mathbf{1 7}$ & $\mathrm{H}$ & $\mathrm{Br}$ & $\mathrm{H}$ & $\mathrm{OH}$ & $\mathrm{C}=\mathrm{O}$ & $\sim 10,000$ \\
$\mathbf{1 8}$ & $\mathrm{H}$ & $\mathrm{H}$ & $\mathrm{F}$ & $\mathrm{Br}$ & $\mathrm{C}=\mathrm{O}$ & 8.1 \\
$\mathbf{1 9}$ & $\mathrm{H}$ & $\mathrm{Br}$ & $\mathrm{H}$ & $\mathrm{Br}$ & $\mathrm{C}=\mathrm{O}$ & 10,347 \\
\hline
\end{tabular}

\subsection{Methoxy $\left(\mathrm{OCH}_{3}\right)$ Group}

The epidermal growth factor receptor (EGFR) is one of the transmembrane receptor tyrosine kinase ErbB family [16]. It plays crucial roles in regulating cell proliferation [17], apoptosis [18], and migration [19]. As such, overexpression and/or mutation of EGFR are associated with the formation of malignant cells [20]. The activation of EGFR also stimulates vascular endothelial growth factor (VEGF), which helps to induce tumour angiogenesis [21]. The main steps in the induction of angiogenesis are mediated via a specific VEGF receptor, VEGFR-2 [22]. Therefore, EGFR and VEGFR-2 are important targets in cancer therapy, especially to inhibit metastasis and angiogenesis. In order to discover better anticancer agents, a series of 4-anilino-quinazoline derivatives were synthesised and tested for EGFR and VEGFR-2 inhibitory activities (Figure 5) [23]. The data (Table 4) showed that analogues

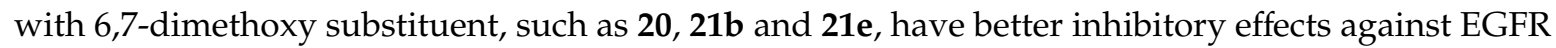
and VEGFR-2 compared to the corresponding analogues 21a, 21c, 21f, which were replaced by a dioxolane ring. 


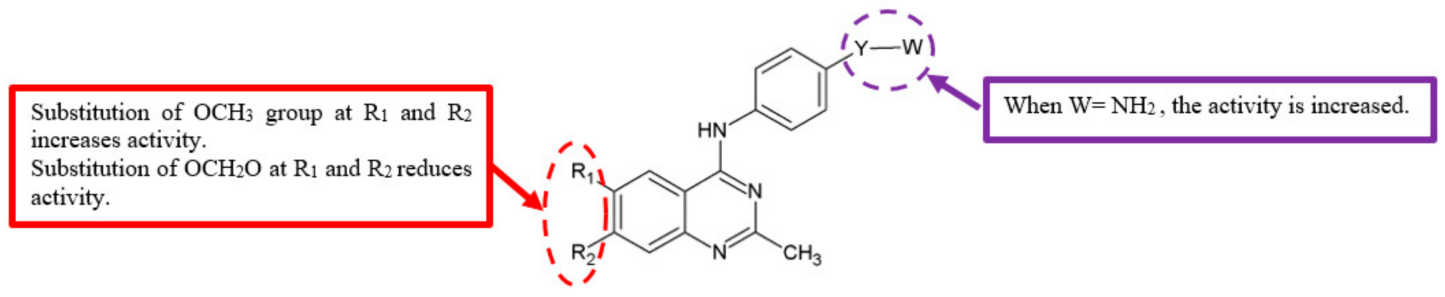

Figure 5. SAR study of 4-anilino-quinazoline derivatives.

Table 4. SAR study of 4-anilino-quinazoline derivatives.

\begin{tabular}{|c|c|c|c|c|c|}
\hline Compounds & $\mathbf{R}_{1}, \mathbf{R}_{2}$ & $\mathbf{Y}$ & $\mathbf{W}$ & $\begin{array}{c}\text { Inhibitory } \\
\text { Activity on } \\
\text { EGFR }\left(\mathrm{IC}_{50}, \mu \mathrm{M}\right)\end{array}$ & $\begin{array}{c}\text { Inhibitory Activity } \\
\text { on VEGFR-2 } \\
\left(\mathrm{IC}_{50}, \mu \mathrm{M}\right)\end{array}$ \\
\hline 20 & $\mathrm{OCH}_{3}, \mathrm{OCH}_{3}$ & $\mathrm{SO}_{2}$ & & 9.70 & 7.79 \\
\hline $21 a$ & $\mathrm{OCH}_{2} \mathrm{O}$ & $\mathrm{SO}_{2}$ & & $>100$ & $>100$ \\
\hline $21 b$ & $\mathrm{OCH}_{3}, \mathrm{OCH}_{3}$ & $\mathrm{SO}_{2}$ & $\mathrm{CH}_{3}$ & 61.5 & $>100$ \\
\hline $21 c$ & $\mathrm{OCH}_{2} \mathrm{O}$ & $\mathrm{SO}_{2}$ & $\mathrm{CH}_{3}$ & $>100$ & $>100$ \\
\hline 21d & $\mathrm{OCH}_{3}, \mathrm{OCH}_{3}$ & $\mathrm{SO}_{2}$ & $\mathrm{NH}_{2}$ & 2.37 & 1.02 \\
\hline $21 e$ & $\mathrm{OCH}_{3}, \mathrm{OCH}_{3}$ & - & $\mathrm{N}\left(\mathrm{CH}_{3}\right)_{2}$ & 36.0 & 39.3 \\
\hline $21 \mathrm{f}$ & $\mathrm{OCH}_{2} \mathrm{O}$ & - & $\mathrm{N}\left(\mathrm{CH}_{3}\right)_{2}$ & $>100$ & $>100$ \\
\hline $21 \mathrm{~g}$ & $\mathrm{OCH}_{3}, \mathrm{OCH}_{3}$ & $\mathrm{C}=\mathrm{O}$ & $\mathrm{NH}_{2}$ & 0.90 & 1.17 \\
\hline
\end{tabular}

In another study, the compound (E)-6-methoxy-3-(4-methoxyphenyl)-2-[2-(5-nitrofuran-2yl)vinyl]quinoline 22 showed weak cytotoxicity in all of the cancer and normal cell lines investigated but had the ability to inhibit cell migration and invasion [24]. Therefore, it can be deduced that the quinoline ring with C-6 methoxy group substitution contributes greatly to inhibit metastasis (Figure 6). Furthermore, combretastatin A4 (CA-4), a known antiangiogenesis agent, has also been found to contain methoxy groups [25]. Thus, methoxy groups are potential contributors to the antimetastatic effects.

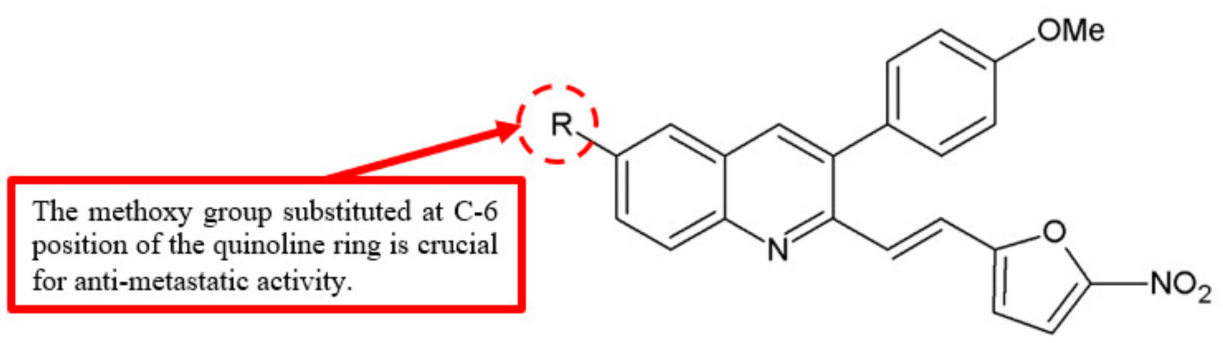

Figure 6. SAR study of 2-furanylvinylquinoline derivative 22.

Transendothelial migration and invasion of tumour cells through the vascular endothelial cell layer are crucial steps in metastasis formation [26]. Thus, Zhou and his team evaluated the potential of a series of 4-methyl-2-(4-pyridinyl)thiazole-5-carboxamide derivatives in inhibiting HUVEC cells migration (Figure 7) [27]. Based on their results (Table 5), analogue 23 exhibited approximately twice the $\mathrm{IC}_{50}$ value compared to $24 \mathrm{a}\left(\mathrm{IC}_{50}=6.0 \pm 1.6\right.$ vs. $\left.3.4 \pm 0.2 \mu \mathrm{M}\right)$. This suggested the antimigration 
effect is higher in compounds with substitution of phenyl $\left(R_{7}\right)$ by electron-donating groups, such as methoxy, compared to those with electron-withdrawing groups, such as chloro and nitro.

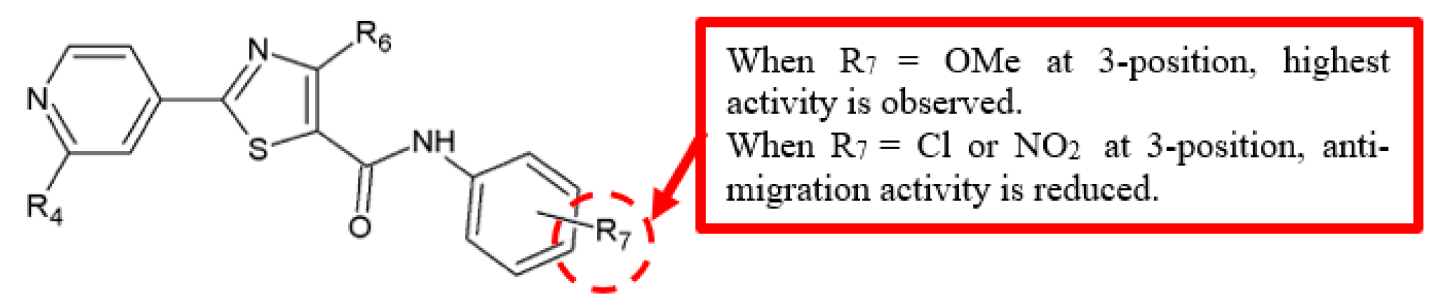

Figure 7. SAR study of 4-methyl-2-(4-pyridinyl)thiazole-5-carboxamide derivatives.

Table 5. SAR study of 4-methyl-2-(4-pyridinyl)thiazole-5-carboxamide derivatives.

\begin{tabular}{ccccc}
\hline \multirow{2}{*}{ Compounds } & $\mathbf{R}_{\mathbf{4}}$ & $\mathbf{R}_{\mathbf{6}}$ & $\mathbf{R}_{\mathbf{7}}$ & Anti-Migration Activity $\left(\mathrm{IC}_{\mathbf{5 0}, \boldsymbol{\mu M})}\right.$ \\
\cline { 5 - 5 } & & - & - & HUVEC \\
\hline $\mathbf{2 3}$ & $\mathrm{n}-\mathrm{Pr}$ & $\mathrm{Me}$ & 3'-OMe $^{\prime}-\mathrm{O}$ & $6.0 \pm 1.6$ \\
$\mathbf{2 4 a}$ & $\mathrm{n}-\mathrm{Pr}$ & $\mathrm{Me}$ & $3^{\prime}-\mathrm{Cl}$ & $3.4 \pm 0.2$ \\
$\mathbf{2 4 b}$ & $\mathrm{n}-\mathrm{Pr}$ & $\mathrm{Me}$ & $3^{\prime}-\mathrm{NO}_{2}$ & $6.8 \pm 2.3$ \\
$\mathbf{2 4 c}$ & & &
\end{tabular}

In a study by Wu et al., EF24 analogues were analysed against lung cancer cell lines for their anticancer ability (Figure 8) [28]. Notably, compound 26 with three methoxy groups attached to its side showed greater cytotoxicity than EF24, 25 (Table 6). Furthermore, compound 26 also exhibited significant antimigration effect against A549 cells. Together, the findings from these studies indicate the importance of methoxy group in the antimetastatic activity of anticancer compounds.

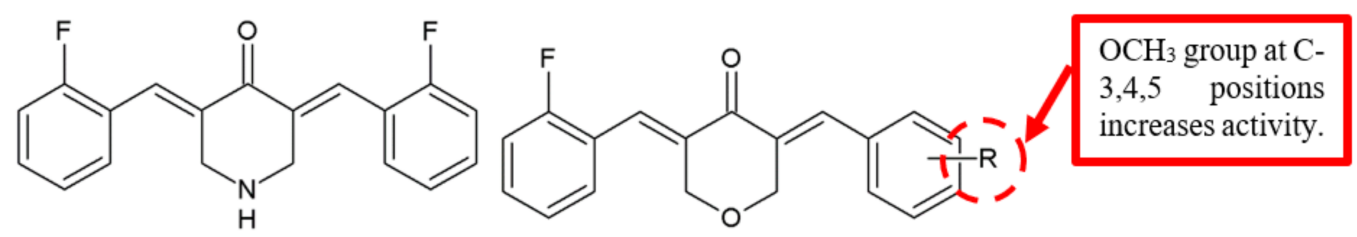

Figure 8. SAR study of EF24 derivatives.

Table 6. SAR study of EF24 derivatives.

\begin{tabular}{|c|c|c|c|c|c|}
\hline \multirow{2}{*}{ Compounds } & \multirow{2}{*}{$\mathbf{R}$} & \multicolumn{3}{|c|}{ Anti-Proliferation Activity $\left(\mathrm{IC}_{50}, \mu \mathrm{M}\right)$} & \multirow{2}{*}{$\begin{array}{c}\begin{array}{c}\text { Migration Rate at the } \\
\text { Concentration of } 20 \mu \mathrm{M}(\%)\end{array} \\
\text { A549 }\end{array}$} \\
\hline & & A549 & LLC & H1650 & \\
\hline EF24, 25 & - & $7.1 \pm 3.2$ & $8.4 \pm 3.0$ & $14.6 \pm 10$ & - \\
\hline 26 & $3,4,5-\mathrm{OCH}_{3}$ & $6.3 \pm 0.3$ & $6.1 \pm 0.9$ & $6.8 \pm 0.3$ & 37.9 \\
\hline
\end{tabular}

\subsection{Methyl $\left(\mathrm{CH}_{3}\right)$ Groups}

The methyl group is another functional group that has been identified to be essential for the anticancer effects of a compound (Figure 9). In a study by Miyanaga et al., when methyl groups are substituted at the dibenzodiazepinone core of BU-4664L, both anti-invasive and antiangiogenic activities were significantly increased (Table 7) [29]. Notably, the methylated compound 27 exhibited a significantly higher antimigration effect of human umbilical vein endothelial cells (HUVEC) with an $\mathrm{IC}_{50}$ value of $7.6 \mu \mathrm{g} / \mathrm{mL}(=15 \mathrm{nM})$. Moreover, this analogue also displayed a remarkable antiangiogenic effect with an $\mathrm{IC}_{50}$ value of $0.11 \mu \mathrm{g} / \mathrm{mL}$. 


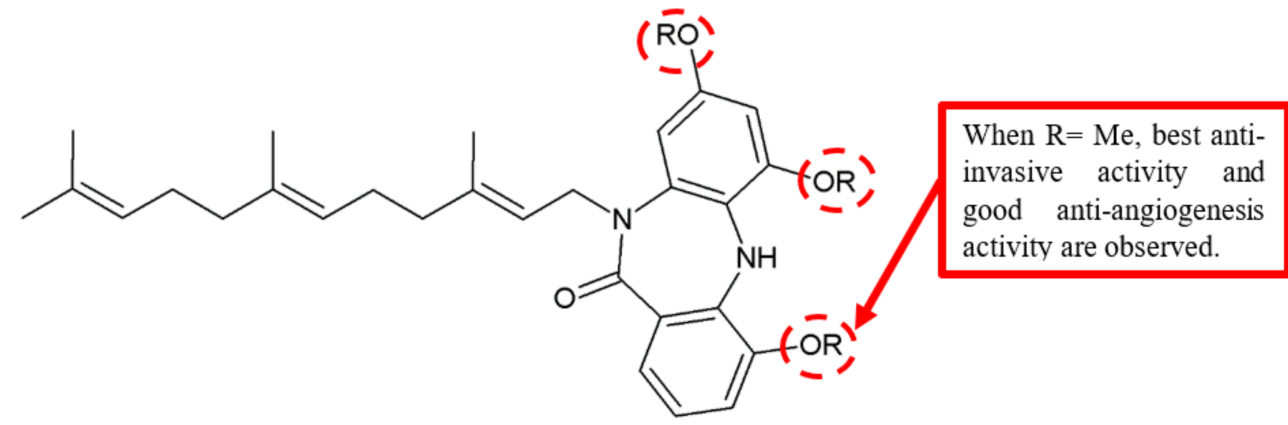

Figure 9. SAR study of BU-4664L derivative 27.

Table 7. SAR study of BU-4664L derivative 27.

\begin{tabular}{|c|c|c|c|c|c|c|c|}
\hline \multirow{3}{*}{ Compounds } & \multirow{3}{*}{ Side Chain } & \multirow{3}{*}{$\mathbf{R}$} & \multicolumn{5}{|c|}{$\mathrm{IC}_{50}(\mu \mathrm{g} / \mathrm{mL})$} \\
\hline & & & \multicolumn{2}{|c|}{ Anti-Invasive Activity } & \multirow{2}{*}{$\begin{array}{l}\text { Anti-Angiogenic } \\
\text { Activity }\end{array}$} & \multicolumn{2}{|c|}{$\begin{array}{c}\text { Inhibition of Cellular } \\
\text { Motility }\end{array}$} \\
\hline & & & $\begin{array}{l}\text { Colon } \\
26-\mathrm{L} 5\end{array}$ & Renca & & Colon 26-L5 & HUVEC \\
\hline 27 & Saturated & $\mathrm{Me}$ & 1.0 & 0.78 & 0.11 & 0.67 & 0.0076 \\
\hline
\end{tabular}

Isomalyngamides are the secondary metabolites isolated from the marine cyanobacterium Lyngbya majuscule [30]. Chang and his group synthesised the analogues of isomalyngamide A and further examined the effectiveness of the compounds against tumour cell migration [31]. The base-sensitive methylene proton ( $\left.\mathrm{H}^{\prime}\right)$ was replaced with a methyl group, a substitute important to restrict chemical alkylation, in the two analogues, 28 and 29 (Figure 10). Although both analogues did not affect MDA-MB-231 cell proliferation at $50 \mu \mathrm{M}$, they completely inhibited cell migration with $\mathrm{IC}_{50}$ values of $22.7 \mu \mathrm{M}$ and $29.9 \mu \mathrm{M}$, respectively (Table 8). Hence, this finding highlighted that methyl group at $\mathrm{H}^{\prime}$ is critical for the inhibition of cancer cell migration.

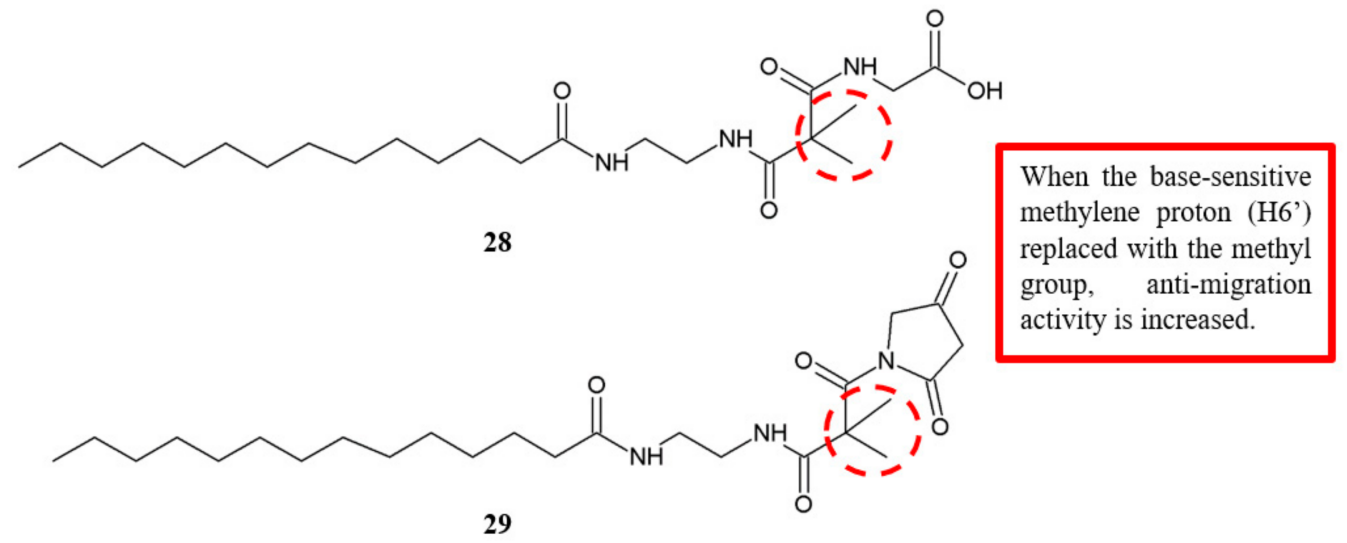

Figure 10. SAR study of isomalyngamide A derivatives.

Table 8. SAR study of isomalyngamide A derivatives.

\begin{tabular}{cccc}
\hline \multirow{2}{*}{ Compounds } & \multicolumn{2}{c}{$\begin{array}{c}\text { Percentage of Cell Proliferation Inhibition at } \\
\mathbf{2 0} \boldsymbol{\mu M}(\boldsymbol{\%})\end{array}$} & $\begin{array}{c}\text { Anti-Migration Activity } \\
\left(\mathbf{I C}_{50}, \boldsymbol{\mu M}\right)\end{array}$ \\
\cline { 2 - 4 } & $\mathbf{M C F - 7}$ & MDA-MB-231 & MDA-MB-231 \\
\hline 28 & $7 \%$ & $0 \%$ & $22.7 \pm 1.3$ \\
29 & $19 \%$ & $0 \%$ & $29.9 \pm 0.6$ \\
\hline
\end{tabular}


Dao and colleagues reported the antiangiogenic activity of novel diarylamino-1,3,5-triazine analogues on HUVEC cells (Figure 11) [32]. Since FAK is related to the antiangiogenic activity, the inhibition of FAK was evaluated upon treatment with the compounds. SAR analysis for various substitutions at the position $\mathrm{R}$ on the triazine ring in the compounds showed that attachment of a methyl group at compound $\mathbf{3 2}$ increased the inhibitory potency substantially, as compared with compound 30 (Table 9).

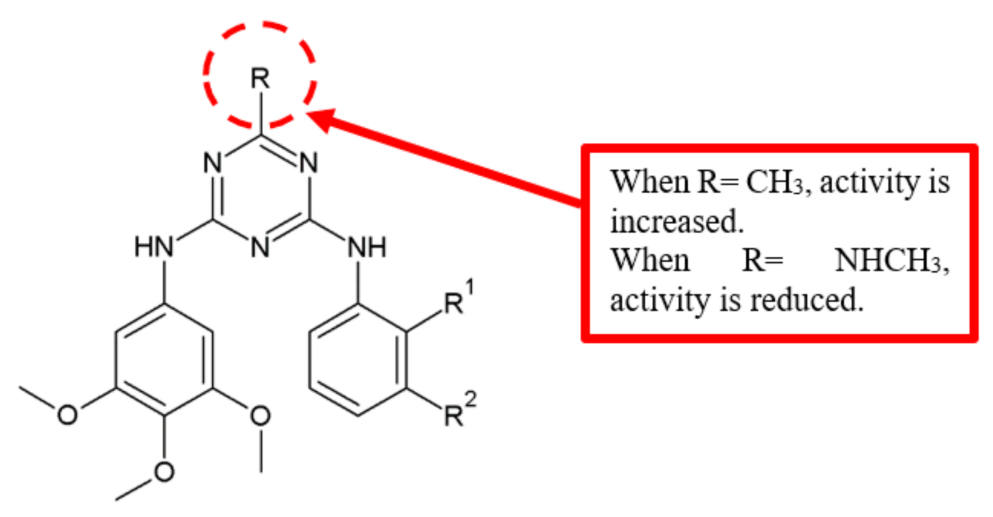

Figure 11. SAR study of diarylamino-1,3,5-triazine derivatives.

Table 9. SAR study of diarylamino-1,3,5-triazine derivatives.

\begin{tabular}{|c|c|c|c|c|c|}
\hline \multirow{2}{*}{ Compounds } & \multirow{2}{*}{$\mathbf{R}^{1}$} & \multirow{2}{*}{$\mathbf{R}^{2}$} & \multirow{2}{*}{$\mathbf{R}$} & $\begin{array}{c}\text { FAK Inhibitory } \\
\text { Activity-FRET }\left(\mathrm{IC}_{50}, \mu \mathrm{M}\right)\end{array}$ & $\begin{array}{l}\text { Anti-Proliferation } \\
\text { Activity }\left(\mathrm{IC}_{50}, \mu \mathrm{M}\right)\end{array}$ \\
\hline & & & & \multicolumn{2}{|c|}{ HUVEC } \\
\hline 30 & $\mathrm{NHSO}_{2} \mathrm{CH}_{3}$ & $\mathrm{H}$ & $\mathrm{Cl}$ & $41.9 \pm 4.6$ & $9.5 \pm 1.0$ \\
\hline 31 & $\mathrm{NHSO}_{2} \mathrm{CH}_{3}$ & $\mathrm{H}$ & $\mathrm{NHCH}_{3}$ & $65.9 \pm 9.6$ & $34.2 \pm 7.6$ \\
\hline 32 & $\mathrm{NHSO}_{2} \mathrm{CH}_{3}$ & $\mathrm{H}$ & $\mathrm{CH}_{3}$ & $7.9 \pm 0.9$ & $8.5 \pm 0.4$ \\
\hline
\end{tabular}

\subsection{Amino Group $\left(\mathrm{NH}_{2}\right)$}

A study of 4-anilino-quinazoline derivatives for EGFR and VEGFR-2 inhibitory activities was performed by Barbosa et al. in 2013 (Figure 5) [23]. The presence of a hydrogen bond donor at the para position of the aniline moiety translated to compounds with significantly lower $\mathrm{IC}_{50}$ values, especially compounds 21d $\left(\mathrm{IC}_{50}=2.37 \mu \mathrm{M}\right.$ for EGFRwt and $1.02 \mu \mathrm{M}$ for VEGFR-2) and 21g $\left(\mathrm{IC}_{50}=0.90 \mu \mathrm{M}\right.$ for EGFRwt and $1.17 \mu \mathrm{M}$ for VEGFR-2) with the attachment of amino group (Table 4). The findings suggest that the amino group's ability to donate hydrogen bond is crucial for EGFR and VEGFR-2 inhibitory activities.

Newly synthesised triarylethylene analogues were analysed for anticancer activity against breast cancer cell lines (Figure 12) [33]. Among the compounds, analogue 33 with an attached amino group exhibited significant enhancement of cytotoxicity with lower $\mathrm{IC}_{50}$ values compared to tamoxifen and ospemifene against MCF-7 and MDA-MB-231 breast cancer cell lines (Table 10). To further verify whether these analogues show anti-invasive and antimetastatic effects on MDA-MB-231, Kaur et al. analysed the in vitro antimigration activity and the expression levels of proteins related to adhesion, migration and metastasis [33]. They identified compound 33 attached with an amino group as the most effective analogue (Table 10). Hence, the amino substitution on triarylethylene analogues is vital for the enhancement of antiproliferation and antimetastatic activities. 


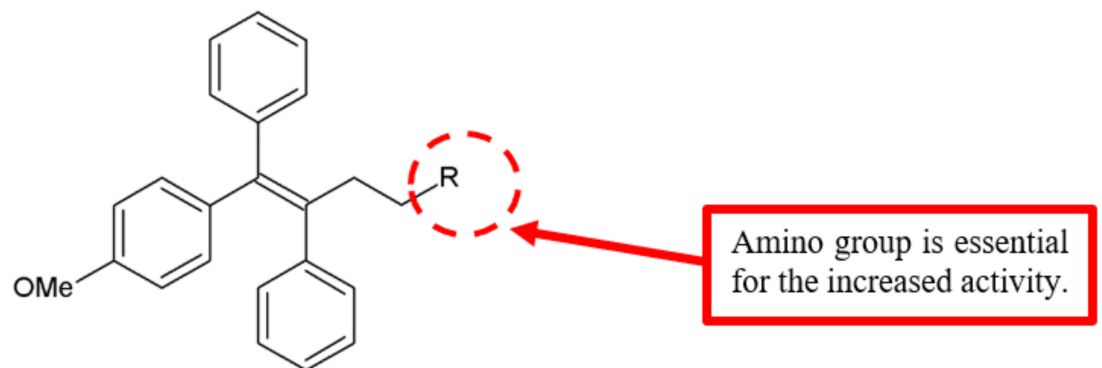

Figure 12. SAR study of triarylethylene derivatives.

Table 10. SAR study of triarylethylene derivatives.

\begin{tabular}{|c|c|c|c|c|}
\hline \multirow{2}{*}{ Compounds } & \multirow{2}{*}{$\mathbf{R}$} & \multicolumn{2}{|c|}{$\begin{array}{l}\text { Anti-Proliferation Activity } \\
\qquad\left(\mathrm{IC}_{50}, \mu \mathrm{M}\right)\end{array}$} & \multirow{2}{*}{$\begin{array}{c}\text { Migration Rate at the } \\
\text { Concentration of } 1 \mu \mathrm{M}(\%)\end{array}$} \\
\hline & & MDA-MB-231 & MCF-7 & \\
\hline 33 & $\mathrm{NH}_{2}$ & $11.4 \pm 4.2$ & $16.9 \pm 7.7$ & 25 \\
\hline Tamoxifen & - & $>50$ & 50 & - \\
\hline Ospemifene & - & $>50$ & $>50$ & $>70 \%$ \\
\hline
\end{tabular}

Matrix metalloproteinases (MMPs) are related to cancer invasion and metastasis [34], and overexpression of MMPs causes breakdown of extracellular matrix (ECM), which can promote tumour invasion [35]. Members of this family, MMP-2 and MMP-9, are also critical in stimulating angiogenesis of tumour cells [36]; therefore, they are regarded as suitable targets for anticancer drugs [37]. Song et al. evaluated the inhibitory activities of synthetic benzamide Ilomastat analogues against MMP-2 and MMP-9 (Figure 13) [38]. Among these analogues, 35a derivative substituted with amino group at the 2-position exhibited significant higher inhibition $\left(\mathrm{IC}_{50}=0.19 \mathrm{nM}\right)$ of $\mathrm{MMP}-2$ compared to Ilomastat, $34\left(\mathrm{IC}_{50}=0.94 \mathrm{nM}\right)$ (Table 11). However, when the 2-amino group was modified to the 3-position or was acylated, both analogues lost potency against MMP-2 compared to 35a, and yet, they showed better inhibition against MMP-9. Furthermore, modifying the substituent at the 4-position caused a lower inhibition of MMP-2, either through the introduction of an electron-donating or electron-withdrawing group. Thus, the inhibition of MMP-2 was not only influenced by the substitution of the amino group at the 2-position but also affected by the substituents at the 4-position.

When $\mathrm{R}_{1}=\mathrm{NH}_{2}$ at $\mathrm{C}-2$ position, inhibition against MMP-2 is increased. Inhibition against MMP-9 is increased when 2-amino group is modified to C3 position or 2-amino group is acylated. Inhibitory activities against MMP-2 is not only influenced by substitution of the amino group at C-2 position.

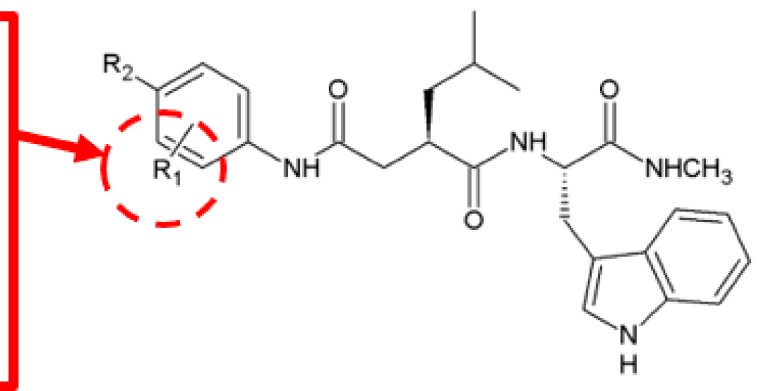

Figure 13. SAR study of benzamide Ilomastat derivatives. 
Table 11. SAR study of benzamide Ilomastat derivatives.

\begin{tabular}{|c|c|c|c|c|}
\hline \multirow{2}{*}{ Compounds } & \multirow{2}{*}{$\mathbf{R}_{1}$} & \multirow{2}{*}{$\mathbf{R}_{2}$} & \multicolumn{2}{|c|}{ Inhibitory Activity $\left(\mathrm{IC}_{50}, \mathrm{nM}\right)$} \\
\hline & & & MMP-2 & MMP-9 \\
\hline Ilomastat, 34 & - & - & 0.94 & 0.55 \\
\hline $35 a$ & $2-\mathrm{NH}_{2}$ & $\mathrm{H}$ & 0.19 & 1579.01 \\
\hline $35 b$ & $2-\mathrm{NH}_{2}$ & $\mathrm{~F}$ & 2.20 & 7.75 \\
\hline $35 c$ & $2-\mathrm{NH}_{2}$ & $\mathrm{CF}_{3}$ & $>10^{4}$ & $>10^{4}$ \\
\hline $35 d$ & $2-\mathrm{NH}_{2}$ & $\mathrm{COPh}$ & $>10^{4}$ & $>10^{4}$ \\
\hline $35 e$ & $2-\mathrm{NH}_{2}$ & $\mathrm{CH}_{3}$ & $>10^{4}$ & 7297.04 \\
\hline $35 \mathrm{f}$ & $2-\mathrm{NH}_{2}$ & $\mathrm{Br}$ & 21.80 & 27.32 \\
\hline $35 \mathrm{~g}$ & 2-NHCOCH 3 & $\mathrm{H}$ & $>10^{4}$ & 155.19 \\
\hline $35 \mathrm{~h}$ & $3-\mathrm{NH}_{2}$ & $\mathrm{H}$ & 2.05 & 13.52 \\
\hline
\end{tabular}

\subsection{Hydroxy (OH) Group}

SAR study on brartemicin analogues conducted by Jiang et al. [10] showed that anti-invasive activity was moderately active when hydroxy group was substituted at the 2- or 4-position of the benzoic acid ring. Both hydroxyl substituted analogues $\mathbf{3 d}$ and 4 maintained the anti-invasive activity at an $\mathrm{IC}_{50}$ of not more than $1.0 \mu \mathrm{g} / \mathrm{mL}$, although with slightly less potency compared to the natural compound 2 (Table 1 ).

\subsection{Nitro $\left(\mathrm{NO}_{2}\right)$ Group}

In the examination of 4-methyl-2-(4-pyridinyl)thiazole-5-carboxamide derivatives in inhibiting HUVEC cells migration by Zhou and colleagues, it was found that analogue 24a exhibited significantly stronger inhibition compared to analogue 23 ( $\mathrm{IC}_{50}=3.4 \pm 0.2$ vs. $6.0 \pm 1.6 \mu \mathrm{M}$ ) (Table 5) [27]. Thus, the findings suggest that phenyl $\left(\mathrm{R}_{7}\right)$ substitution with the electron-withdrawing nitro groups results in a weaker antimigration effect than electron-donating groups such as methoxy.

\subsection{Bromo (Br) Group}

Wu et al. synthesised a series of 2,3-diaryl-4-thiazolidinone analogues and evaluated their effects against tumour cell proliferation and migration [39]. Interestingly, most of the 2-(3-(arylalkyl amino carbonyl) phenyl)-3-(2-methoxy-phenyl)-4-thiazolidinone derivatives showed high antiproliferation effect against non-small lung cancer cell line A549 and breast cell line MDA-MB-231. Among these analogues, compound $\mathbf{3 6}$ with the bromo substituent attached to the phenylethyl amino group (Figure 14) exhibited the highest antimigration effect with an $\mathrm{IC}_{50}$ of less than $0.05 \mathrm{mM}$ (Table 12). These results strongly suggest that the bromo group is an important structural requirement to inhibit the migration of cancer cells.

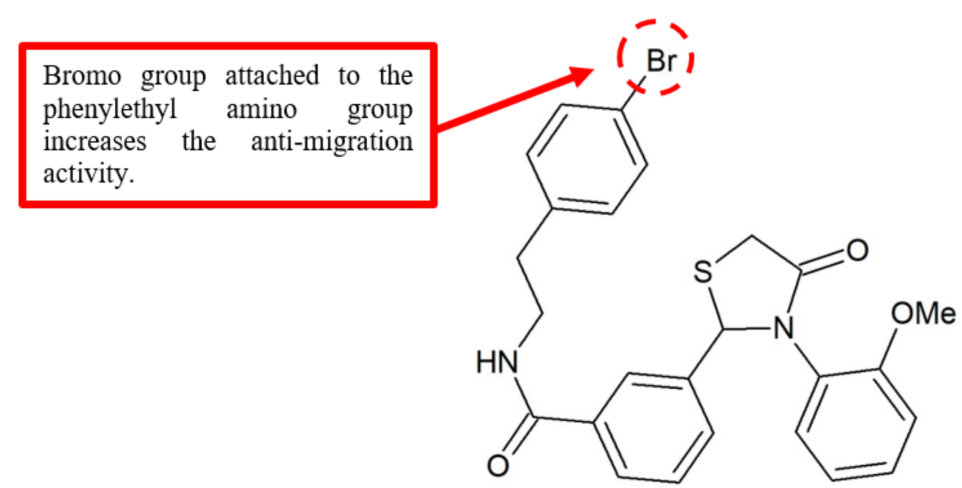

Figure 14. SAR study of 2,3-diaryl-4-thiazolidinone derivative 36. 
Table 12. SAR study of 2,3-diaryl-4-thiazolidinone derivative 39.

\begin{tabular}{cccc}
\hline \multirow{2}{*}{ Compounds } & \multicolumn{2}{c}{ Anti-Proliferation Activity $\left(\mathrm{IC}_{50}, \mu \mathrm{M}\right)$} & Anti-Migration Activity $\left(\mathrm{IC}_{50}, \mu \mathrm{M}\right)$ \\
\cline { 2 - 4 } & A549 & MDA-MB-231 & MDA-MB-231 \\
\hline 36 & 0.21 & 0.23 & $<0.05$ \\
\hline
\end{tabular}

\subsection{Chloro (Cl) Group}

The protein STAT3 is a member of the signal transducers and activators of transcription (STATs) family [40], that helps to regulate cell proliferation, apoptosis and metastasis [41]. Inhibition of STAT3 signalling has been demonstrated to prevent metastasis [42] and inhibit angiogenesis [43] in various tumour models, making it a therapeutic cancer target. To synthesise more potent STAT3 inhibitors, Gao and his team [44] developed a series of benzyloxyphenylmethylaminophenol analogues (Figure 15) and tested the inhibition of STAT3 signalling pathway using a STAT3 luciferase reporter method.

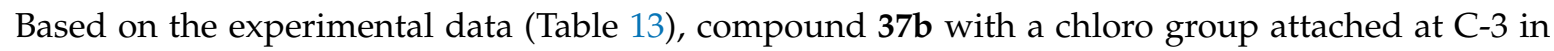
ring $B$ showed lower $\mathrm{IC}_{50}$ value $(1.38 \mu \mathrm{M})$ compared to the compound without chloro group 37a $\left(\mathrm{IC}_{50}=7.71 \mu \mathrm{M}\right)$. Moreover, changing the position of the chloro group from C-3 to C-5 reduced the inhibition the STAT3 activity.

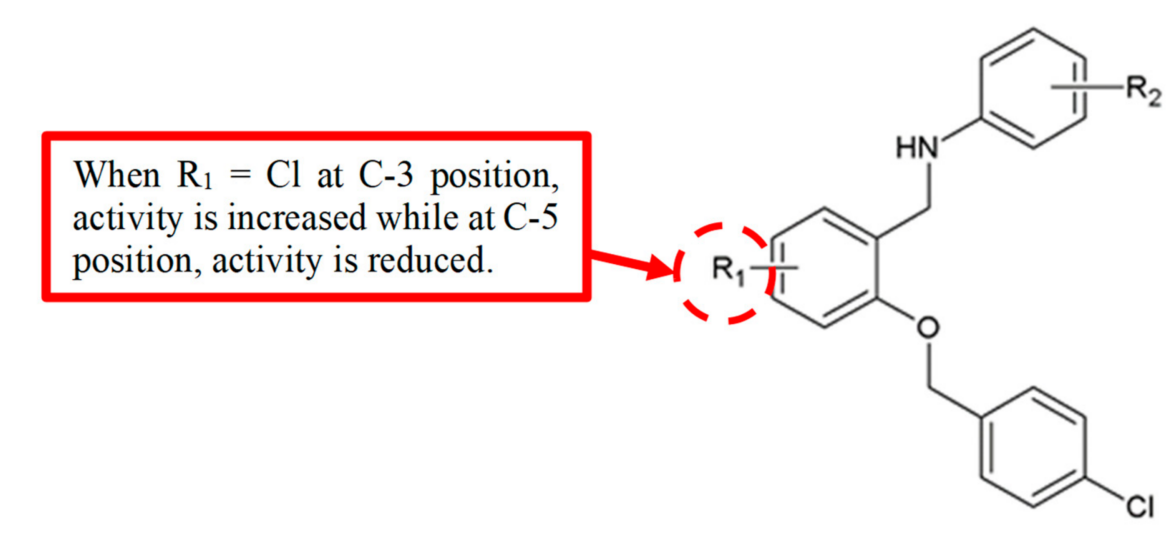

Figure 15. SAR study of benzyloxyphenylmethylaminophenol derivatives.

Table 13. SAR study of benzyloxyphenylmethylaminophenol derivatives.

\begin{tabular}{ccccc}
\hline \multirow{2}{*}{ Compounds } & & & $\begin{array}{c}\text { Inhibitory Activity on STAT3 } \\
\left(\mathbf{R C}_{\mathbf{5 0}}, \boldsymbol{\mu M}\right)\end{array}$ & $\begin{array}{c}\text { Anti-Proliferation } \\
\text { Activity }\left(\mathbf{I C}_{\mathbf{5 0}}, \boldsymbol{\mu M}\right)\end{array}$ \\
\cline { 3 - 5 } & & $\mathbf{R}_{\mathbf{2}}$ & $\mathbf{H e p G 2}$ & MDA-MB-468 \\
\hline $37 \mathbf{a}$ & $\mathrm{H}$ & $4^{\prime}-\mathrm{OH}$ & 7.71 & 9.61 \\
\hline $37 \mathbf{b}$ & $3-\mathrm{Cl}$ & $4^{\prime}-\mathrm{OH}$ & 1.38 & 19.70 \\
\hline $37 \mathrm{c}$ & $5-\mathrm{Cl}$ & $4^{\prime}-\mathrm{OH}$ & 26.68 & 18.83 \\
\hline $37 \mathrm{~d}$ & $5-\mathrm{Cl}$ & $4^{\prime}-\mathrm{SO}_{2} \mathrm{NH}_{2}$ & 35.67 & 24.34 \\
\hline
\end{tabular}

\section{Weak Functional Groups, Their Position and Antimigration Effect}

\subsection{Methoxy $\left(\mathrm{OCH}_{3}\right)$ Group}

Jiang et al. [10] reported that the 2-methoxy substituted brartemicin analogue 3a maintained its anti-invasive activity. The activity increased when methoxy group was substituted at both 2- and 3-positions, whereby the 2,3-dimethoxy-substituted analogue $2 \mathbf{e}$ was more potent than 2,3-dihydroxyl 5 and the natural brartemicin (Table 1). However, the 4-methoxy-substituted 3c, 3,4,5-trimethoxy-substituted $3 \mathbf{f}$ and 3-methoxy-4-flurobenzoic esters $3 \mathrm{~g}$ completely lost the anti-invasive 
ability. Altogether, the results showed that the methoxy group is not a good substituent to the phenyl ring in inhibiting invasiveness.

Parker et al. in 2013 carried out the synthesis of benzoylbenzophenone thiosemicarbazone derivatives and assessed the inhibitory activity against cathepsins L [15]. The activity was diminished when the compound was substituted with a methoxy group. The authors suggested that the reduction in activity was caused by the increase in steric hindrance due to the substitution. As shown in Table 3, p-methoxy analogue 15 exhibited a high $\mathrm{IC}_{50}$ value of $5117 \mathrm{nM}$ and is significantly weaker than unsubstituted analogue 12. Thus, it was concluded that methoxy group does not have an important role in inhibiting cathepsins $\mathrm{L}$.

Additionally, Limtrakul et al. reported the effects of curcumin 38, demethoxycurcumin 39 and bisdemethoxycurcumin 40 (Figure 16) on the expressions of matrix metalloproteinases-2 (MMP-2), matrix metalloproteinases-9 (MMP-9), urokinase plasminogen activator (uPA), membrane Type 1 MMP (MT1-MMP), and tissue inhibitor of metalloproteinases (TIMP-2), in addition to in vitro invasiveness of human fibrosarcoma cells [45]. The compounds $\mathbf{3 9}$ and $\mathbf{4 0}$ had higher antimetastatic potency than $\mathbf{3 8}$ by differentially downregulating the extracellular matrix (ECM) degradation enzymes MMPs and uPA (Table 14). Based on the zymography results, 38, 39 and $\mathbf{4 0}$ significantly decreased the cell secretion of uPA, active-MMP-2 and MMP-9 but not pro-MMP-2 in a dose-dependent manner.

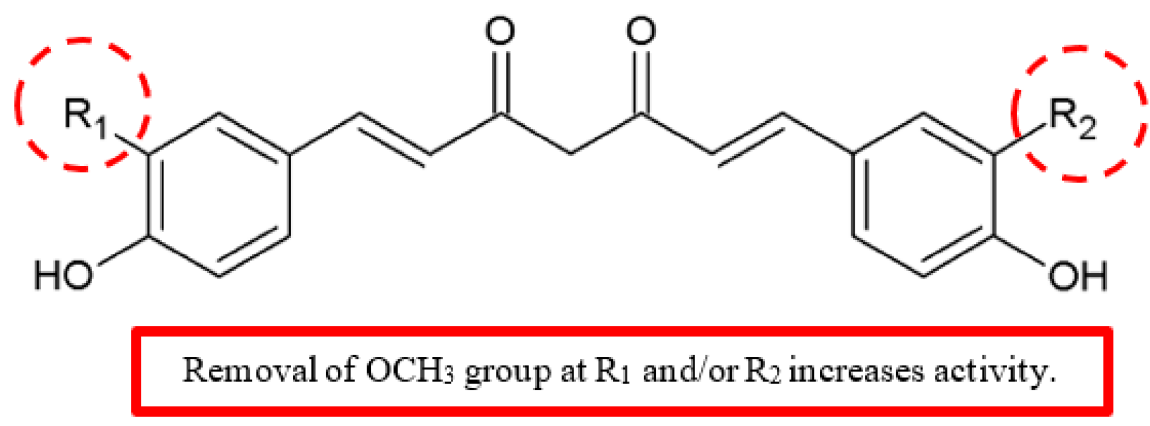

Figure 16. SAR study of curcumin derivatives.

Table 14. SAR study of curcumin derivatives.

\begin{tabular}{ccccccc}
\hline Compounds & $\mathbf{R}_{\mathbf{1}}, \mathbf{R}_{2}$ & $\begin{array}{c}\text { Inhibition of } \\
\text { Active-MMP-2 } \\
\text { Secretion }\end{array}$ & $\begin{array}{c}\text { Inhibition of } \\
\text { Active-MMP-9 } \\
\text { Secretion }\end{array}$ & $\begin{array}{c}\text { Inhibition } \\
\text { of uPA } \\
\text { Secretion }\end{array}$ & $\begin{array}{c}\text { Inhibition of } \\
\text { Collagenase } \\
\text { Activity }\end{array}$ & $\begin{array}{c}\text { Inhibition } \\
\text { of MMP-2 } \\
\text { Activity }\end{array}$ \\
\hline \begin{tabular}{c} 
Curcumin, 38 \\
\cline { 2 - 7 }
\end{tabular} & $\mathrm{OCH}_{3}, \mathrm{OCH}_{3}$ & 9.0 & $>10.0$ & 10.0 & 50.0 & $>50.0$ \\
\hline $\begin{array}{c}\text { Demethoxycurcumin, } \\
\mathbf{3 9}\end{array}$ & $\mathrm{OCH}_{3,-}$ & 6.0 & 8.0 & 7.5 & 47.0 & 45.0 \\
\hline $\begin{array}{c}\text { Bisdemethoxycurcumin, } \\
\mathbf{4 0}\end{array}$ &,-- & 7.0 & $>10.0$ & 7.0 & $>50.0$ & 40.0 \\
\hline
\end{tabular}

The MT1-MMP and TIMP-2 protein expressions reduced when treated with $10 \mu \mathrm{M}$ with 39 and 40 , but the treatment with curcumin showed a slight reduction of MT1-MMP but not TIMP-2. Furthermore, these curcuminoids significantly inhibited activities of three enzymes, namely, collagenase, MMP-2 and MMP-9. The results concluded that the anti-invasion activity of the compounds can be ranked as $40 \geq 39>38$. As shown in Figure 16, the antimetastatic potency of curcumin derivatives is increased by removal of one or two methoxy groups from the benzene ring.

\subsection{Methyl $\left(\mathrm{CH}_{3}\right)$ Groups}

Brartemicin analogues were studied for anti-invasion effect against murine colon 26-L5 carcinoma cells [10]. Among the various functional groups at the 2-position of the benzoic acid ring, 2-methyl 
substitution in analogue $\mathbf{3 b}$ did not result in anti-invasive activity (Figure 2). Hence, methyl groups are not recommended as substituents for antimetastatic activity.

The FAK inhibitory effect of the 1,3,4-oxadiazole analogues was investigated [12]. The SAR analysis indicated that compounds with electron-donating groups showed weaker activity. An example is the methyl substitution in analogues 7, 9 and $\mathbf{1 1}$, with $\mathrm{IC}_{50}$ values in the range of 12.1-33.8 $\mu \mathrm{M}$ (Table 2). Their activity was significantly reduced compared to compounds with an electron-withdrawing group. Succinctly, methyl groups are unfavourable for FAK inhibition.

Foudah et al. discussed the influence of different aromatic esters attached at the C-4 position of sipholenol A analogues on the antimigratory activity (Figure 17) [46]. They discovered that the presence of an electron-donating substituent, such as the methyl group at the para-position of the aromatic moiety $\left(C-5^{\prime}\right)$ of 41 , reduced the antimigratory activity when compared with an electron-withdrawing substituent, such as the fluoro group on 42 (Table 15).

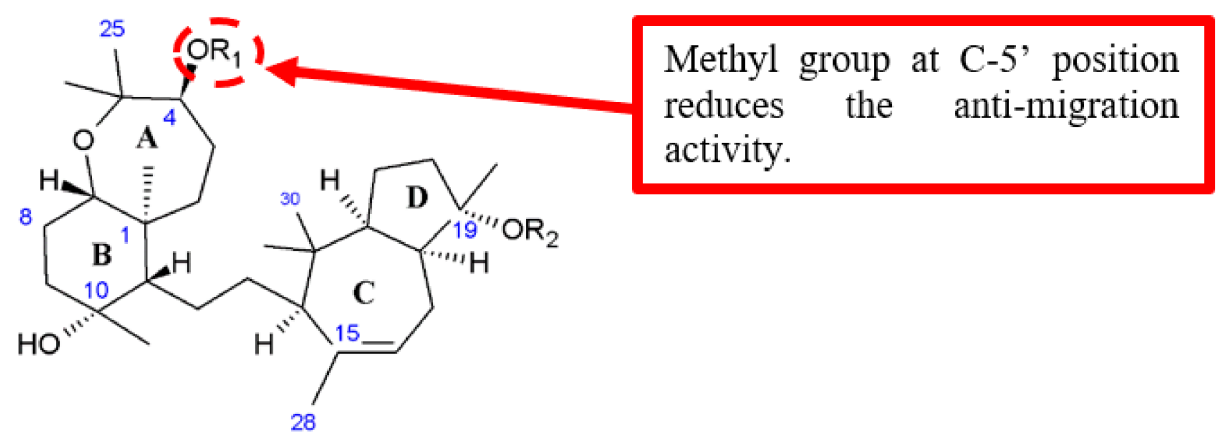

Figure 17. SAR study of sipholenol A derivatives.

Table 15. SAR study of sipholenol A derivatives.

\begin{tabular}{|c|c|c|c|c|c|}
\hline \multirow{2}{*}{ Compounds } & \multirow{2}{*}{$\mathbf{R}_{1}$} & \multirow{2}{*}{$\mathbf{R}_{2}$} & \multicolumn{2}{|c|}{$\begin{array}{l}\text { Anti-Proliferation Activity } \\
\qquad\left(\mathrm{IC}_{50}, \mu \mathrm{M}\right)\end{array}$} & \multirow{2}{*}{$\begin{array}{c}\begin{array}{c}\text { Anti-Migration } \\
\text { Activity }\left(\mathrm{IC}_{50}, \mu \mathrm{M}\right)\end{array} \\
\text { MDA-MB-231 }\end{array}$} \\
\hline & & & MCF-7 & MDA-MB-231 & \\
\hline 41 & & $\mathrm{H}$ & $>50$ & 33.4 & 11.8 \\
\hline 42 & & $\mathrm{H}$ & 33.5 & 11.3 & 2.4 \\
\hline
\end{tabular}

\subsection{Hydroxy (OH) Group}

Benzoylbenzophenone thiosemicarbazone analogues were tested for the inhibition of cathepsins L [15]. It was observed that para substitution of hydroxy at the analogue $\mathbf{1 6}$ resulted in diminished anticancer activity. As shown in Table 3, the $\mathrm{IC}_{50}$ value of 16 was $340 \mathrm{nM}$ and less potent than original analogue 12. As such, the reduced activity was thought to be due to the steric hindrance by the para hydroxyl group. Hence, it is important to select a suitable substituent in order to reduce the steric hindrance effects on the anticancer activity.

Andrographolide derivatives were evaluated against cancer cell for antimigration and anti-invasion activities (Figure 18) [47]. Analogue 44, in which the allylic hydroxyl at C-14 position was removed, had a better antimigration effect in human bladder carcinoma 5637 cells than the original compound 
(43) (Table 16). In other words, the hydroxy group may hinder the antimigration effect on cancer cells, which requires further validation.

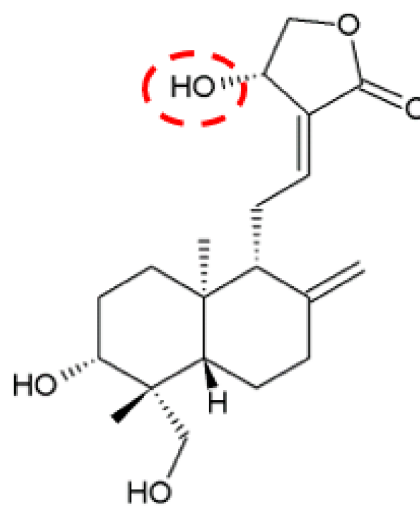

43

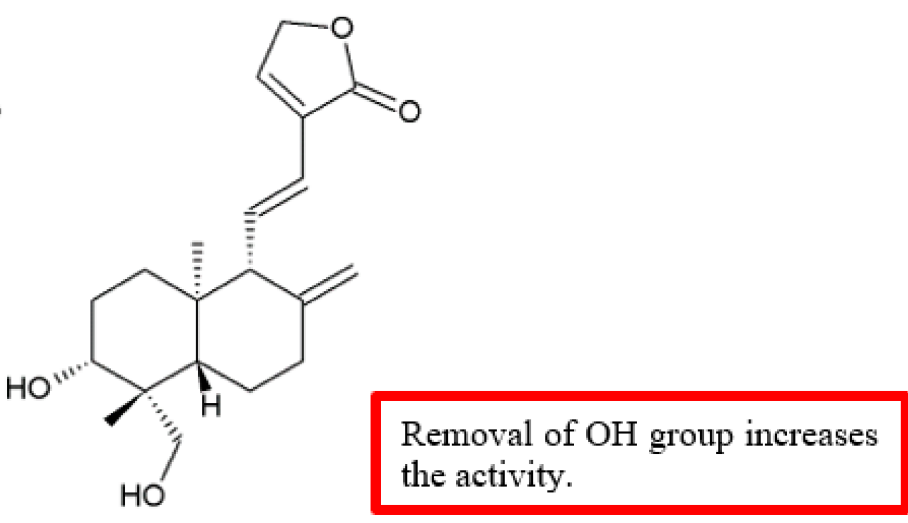

44

Figure 18. SAR study of andrographolide derivatives.

Table 16. SAR study of andrographolide derivatives. Im (\%) refers to the percentage of inhibition on cell migration at $10.0 \mu \mathrm{M}$, except for that of 5637 cells treated by compound 43 at $5 \mu \mathrm{M}$, the minimum effective concentration for cell migration. ${ }^{a}$ No inhibitory activities against cell migration were observed at $10.0 \mu \mathrm{M}$.

\begin{tabular}{cccc}
\hline \multirow{2}{*}{ Compounds } & \multicolumn{3}{c}{ Anti-Migration Activity (Im, \%) } \\
\cline { 2 - 4 } & 5637 & SGC-7901 & PC-3 \\
\hline Andrographolide, 43 & $34.5 \%$ & $20.8 \%$ & $\mathrm{~N}^{\mathrm{a}}$ \\
$\mathbf{4 4}$ & $44.7 \%$ & $\mathrm{~N}^{\mathrm{a}}$ & $\mathrm{N}^{\mathrm{a}}$ \\
\hline
\end{tabular}

\subsection{Bromo (Br) Group}

The benzoylbenzophenone thiosemicarbazone analogues 17 and 19 exhibited a remarkable decrease of cathepsin L inhibition among all the analogues. Both of these compounds have $m$-bromo substituents on the outermost rings of the benzoylbenzophenone molecular template [15]. Moreover, analogue 14 with $p$-bromo substituted bis-thiosemicabazone was unable to inhibit cathepsin $\mathrm{L}$ even at a high concentration of 10,000 $\mathrm{nM}$ (Table 3). Overall, the bromo substituent, which increases the steric bulk on the outermost rings, leads to the reduced inhibitory activity.

\subsection{Chloro (Cl) Group}

The antimigration activity of nine 4-methyl-2-(4-pyridinyl)thiazole-5-carboxamide analogues on HUVEC cells was examined [27], and the results showed that derivatives with substitution of phenyl $\left(R_{7}\right)$ by a chloro group have reduced antimigration effect when compared to the analogue substituted by a methoxy group. The data showed that antimigration activity of chlorinated analogue $\mathbf{2 4 b}$ with $\mathrm{IC}_{50}$ value of $6.8 \pm 2.3$ was weaker than methoxylated analogue 24 a with $\mathrm{IC}_{50}$ value of $3.4 \pm 0.2$ (Table 5).

\subsection{Methylamino $\left(\mathrm{NHCH}_{3}\right)$ Group}

A study on the antiangiogenic activity of novel diarylamino-1,3,5-triazine analogues on HUVEC cells [32] showed that methylamino group attached at the position $\mathrm{R}$ on the triazinic ring of the compound 31 reduced the potency of FAK inhibition (Table 9). Hence, methylamino groups are not suitable as a substituent for antimigration activity. 


\section{Effective Functional Groups, Their Position and Antiproliferation Effect}

\subsection{Chloro (Cl) Group}

In 2001, Trapani et al. [48] synthesised and evaluated imidazobenzothiazole derivatives for cytotoxic activity against several cancer cells. A SAR study (Figure 19) concluded that the introduction of chloro group at the 7-position of the parent compound led to the enhancement of cytotoxic activity (Table 17). Furthermore, analogue 48 was derived from substitution with $\mathrm{Cl}$ atom at the 8-position of the monochloro derivative 45 , which displayed a minimum increase of activity. This finding suggested that the position of chloro substitution could affect antiproliferation activity.

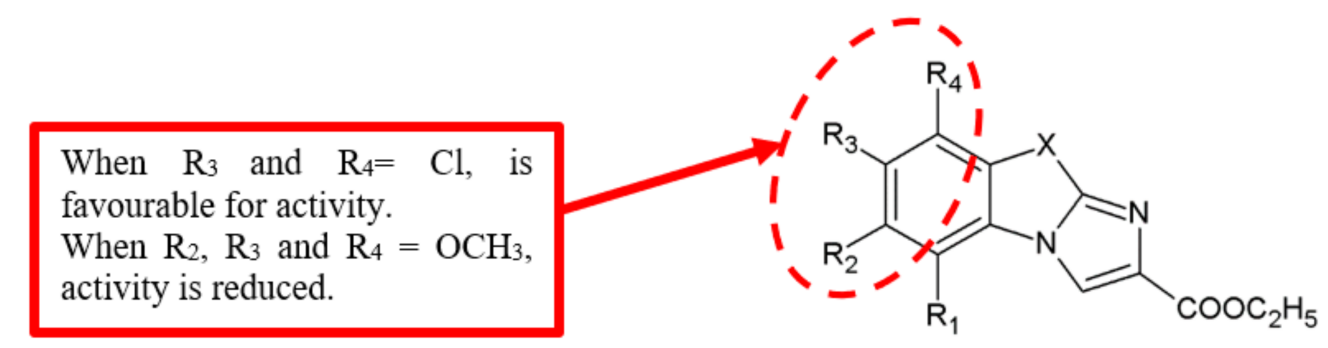

Figure 19. SAR study of imidazobenzothiazole derivatives.

Table 17. SAR study of imidazobenzothiazole derivatives. ${ }^{a}$ Log of molar concentration that inhibits $50 \%$ net cell growth, MG MID—mean graph midpoint.

\begin{tabular}{ccccccc}
\hline Compounds & $\mathbf{X}$ & $\mathbf{R}_{\mathbf{1}}$ & $\mathbf{R}_{\mathbf{2}}$ & $\mathbf{R}_{\mathbf{3}}$ & $\mathbf{R}_{\mathbf{4}}$ & $\mathbf{l o g} \mathbf{M G} \mathbf{M I D} \mathbf{G I}_{\mathbf{5 0}}{\mathbf{~} \mathbf{M})^{\mathbf{a}}}^{\mathbf{a}}$ \\
\hline $\mathbf{4 5}$ & $\mathrm{S}$ & $\mathrm{H}$ & $\mathrm{H}$ & $\mathrm{Cl}$ & $\mathrm{H}$ & -4.74 \\
$\mathbf{4 6}$ & $\mathrm{S}$ & $\mathrm{H}$ & $\mathrm{H}$ & $\mathrm{OCH}_{3}$ & $\mathrm{H}$ & -4.87 \\
$\mathbf{4 7}$ & $\mathrm{S}$ & $\mathrm{H}$ & $\mathrm{OCH}_{3}$ & $\mathrm{OCH}_{3}$ & $\mathrm{H}$ & -4.14 \\
$\mathbf{4 8}$ & $\mathrm{S}$ & $\mathrm{H}$ & $\mathrm{H}$ & $\mathrm{Cl}$ & $\mathrm{Cl}$ & -4.89 \\
$\mathbf{4 9}$ & $\mathrm{S}$ & $\mathrm{H}$ & $\mathrm{OCH}_{3}$ & $\mathrm{OCH}_{3}$ & $\mathrm{OCH}_{3}$ & -4.26 \\
\hline
\end{tabular}

Morales and colleagues [49] examined the antiproliferation activity of purine derivatives against human breast, colon and melanoma cancer cell lines (Figure 20). Their results showed that 2,6-dichloropurine analogues $\mathbf{5 0}$ and $\mathbf{5 1}$ have the most potent activity against the assayed cell lines (Table 18). This SAR information draws attention to the importance of chloro substituents for the antiproliferation activity.

Chloro substituent is important for anti-proliferation activity.<smiles>[R]c1nc([R6])c2ncn(CC(=O)OCC)c2n1</smiles>

$\mathbf{5 0} \mathrm{R}_{2}=\mathrm{R}_{6}=\mathrm{Cl}$<smiles>[R2]c1nc([R6])c2c(ncn2CC(=O)OCC)n1</smiles>

$51 \mathrm{R}_{2}=\mathrm{R}_{6}=\mathrm{Cl}$

Figure 20. SAR study of purine derivatives.

Table 18. SAR study of purine derivatives.

\begin{tabular}{ccccc}
\hline \multirow{2}{*}{ Compounds } & \multicolumn{4}{c}{ Anti-proliferation activity $\left(\right.$ IC $\left._{\mathbf{5 0}}, \boldsymbol{\mu M}\right)$} \\
\cline { 2 - 5 } & MCF-7 & HCT-116 & A-375 & G-361 \\
\hline $\mathbf{5 0}$ & $3.93 \pm 0.04$ & $6.20 \pm 0.05$ & $1.18 \pm 0.03$ & $3.06 \pm 0.01$ \\
$\mathbf{5 1}$ & $5.63 \pm 0.03$ & $6.36 \pm 0.06$ & $4.98 \pm 0.07$ & $5.67 \pm 0.01$ \\
\hline
\end{tabular}


Several novel 8-hydroxyquinoline analogues were synthesised by Freitas et al., and the antiproliferation activity of the compounds were evaluated using several cancer cell lines (Figure 21) [50]. Aromatic rings which had halogen substituents such as fluorine, chlorine, bromine and iodine were chosen to study the electronic and steric impacts of the substituents. Among the halogenated derivatives, the chlorinated analogues 52c and 52e had the best antiproliferative effect (Table 19). The results proposed that chloro substituents exerted enhanced cytostatic activity.

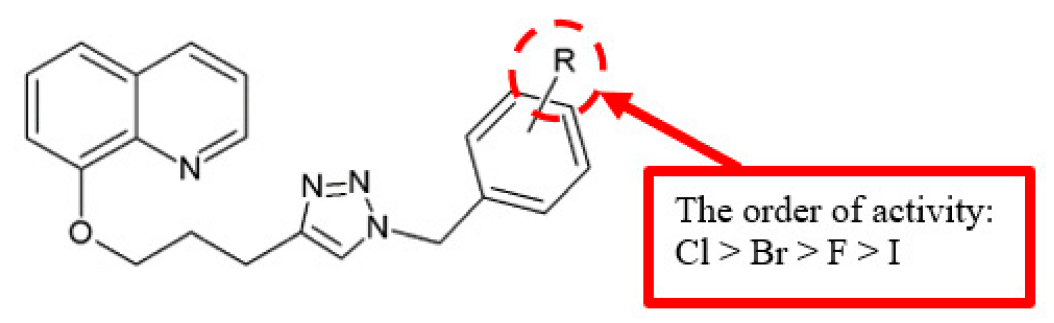

Figure 21. SAR study of 8-hydroxyquinoline derivatives.

Table 19. SAR study of 8-hydroxyquinoline derivatives. ${ }^{\mathrm{a}}$ Log of molar concentration of compound that inhibits cell growth by $50 \%$, MG MID—mean graph midpoint.

\begin{tabular}{ccc}
\hline Compounds & $\mathbf{R}$ & $\log \mathbf{M G ~ M I D ~ G I}_{\mathbf{5 0}} \mathbf{( M )} \mathbf{a}^{\mathbf{a}}$ \\
\hline $\mathbf{5 2 a}$ & $4-\mathrm{I}$ & 1.8 \\
$\mathbf{5 2} \mathbf{b}$ & $4-\mathrm{F}$ & 1.6 \\
$\mathbf{5 2 c}$ & $4-\mathrm{Cl}$ & 0.7 \\
$\mathbf{5 2 d}$ & $4-\mathrm{Br}$ & 1.3 \\
$\mathbf{5 2} \mathbf{e}$ & $2,4,6-(\mathrm{Cl})_{3}$ & 0.7 \\
\hline
\end{tabular}

\subsection{Methoxy $\left(\mathrm{OCH}_{3}\right)$ Group}

SAR analysis of (Z)-1-(1,3-diphenyl-1H-pyrazol-4-yl)-3-(phenylamino)prop-2-en-1-one derivatives revealed that a methoxy group as the electron-donating group attached to the aromatic $B$ ring could contribute to significant cytotoxicity (Figure 22) [51]. Analogues 56, 61, 66, $\mathbf{7 1}$ and 76, with methoxy substitution at B ring, and analogues $57,62,67,72$ and 77 , with 3,4,5,-methoxy substitution, showed better $\mathrm{IC}_{50}$ values than the analogues with an electron-withdrawing group (Table 20).

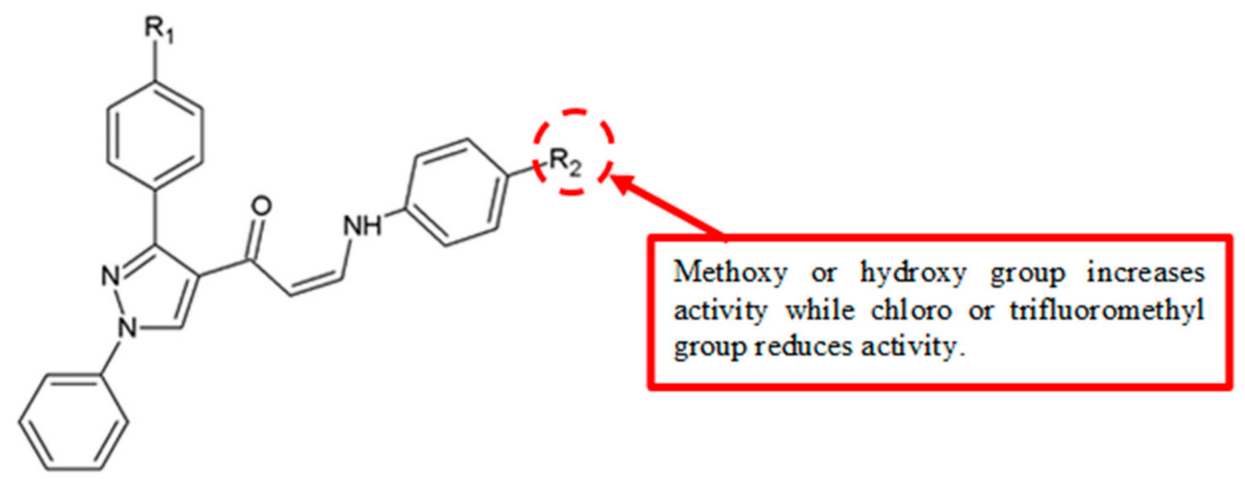

Figure 22. SAR study of (Z)-1-(1,3-diphenyl-1H-pyrazol-4-yl)-3-(phenylamino)prop-2-en-1-one derivatives. 
Table 20. SAR study of (Z)-1-(1,3-diphenyl-1H-pyrazol-4-yl)-3-(phenylamino)prop-2-en-1-one derivatives.

\begin{tabular}{|c|c|c|c|c|c|c|c|}
\hline \multirow{2}{*}{ Compounds } & \multirow{2}{*}{$\mathbf{R}_{\mathbf{1}}$} & \multirow{2}{*}{$\mathbf{R}_{\mathbf{2}}$} & \multicolumn{5}{|c|}{ Anti-proliferation activity $\left(\mathrm{IC}_{50}, \mu \mathrm{M}\right)$} \\
\hline & & & HT29 & PC3 & A549 & U87MG & HaCaT \\
\hline 53 & $\mathrm{H}$ & $\mathrm{Cl}$ & $3.61 \pm 0.56$ & $5.2 \pm 0.93$ & $14.05 \pm 0.76$ & $11.4 \pm 0.29$ & $28.4 \pm 4.1$ \\
\hline 54 & $\mathrm{H}$ & $\mathrm{CF}_{3}$ & $>50$ & $>50$ & $>50$ & $>50$ & $>50$ \\
\hline 55 & $\mathrm{H}$ & $\mathrm{OH}$ & $5.0 \pm 0.96$ & $3.6 \pm 0.65$ & $3.21 \pm 1.2$ & $4.29 \pm 0.89$ & $44.6 \pm 3.6$ \\
\hline 56 & $\mathrm{H}$ & $\mathrm{OMe}$ & $1.56 \pm 0.32$ & $6.4 \pm 1.1$ & $3.25 \pm 0.19$ & $>50$ & $>50$ \\
\hline 57 & $\mathrm{H}$ & 3,4,5-OMe & $9.8 \pm 1.3$ & $5.93 \pm 1.7$ & $6.34 \pm 0.83$ & $2.35 \pm 0.65$ & $36.2 \pm 1.8$ \\
\hline 58 & $\mathrm{~F}$ & $\mathrm{Cl}$ & $4.6 \pm 0.61$ & $3.8 \pm 0.56$ & $6.7 \pm 0.85$ & $8.9 \pm 1.3$ & $21.3 \pm 2.1$ \\
\hline 59 & $\mathrm{~F}$ & $\mathrm{CF}_{3}$ & $>50$ & $>50$ & $>50$ & $>50$ & $>50$ \\
\hline 60 & $\mathrm{~F}$ & $\mathrm{OH}$ & $1.9 \pm 0.21$ & $2.6 \pm 0.19$ & $1.5 \pm 0.45$ & $4.7 \pm 0.8$ & $16.3 \pm 1.2$ \\
\hline 61 & F & $\mathrm{OMe}$ & $3.2 \pm 0.9$ & $4.6 \pm 0.7$ & $8.9 \pm 0.51$ & $2.5 \pm 0.61$ & $19.6 \pm 0.93$ \\
\hline 62 & $\mathrm{~F}$ & 3,4,5-OMe & $7.77 \pm 0.96$ & $4.89 \pm 1.35$ & $9.35 \pm 1.8$ & $12.6 \pm 2.1$ & $32.8 \pm 3.4$ \\
\hline 63 & $\mathrm{Cl}$ & $\mathrm{Cl}$ & $4.65 \pm 0.63$ & $3.89 \pm 0.79$ & $3.67 \pm 0.3$ & $13.12 \pm 1.2$ & $23.4 \pm 3.7$ \\
\hline 64 & $\mathrm{Cl}$ & $\mathrm{CF}_{3}$ & $>50$ & $>50$ & $>50$ & $>50$ & $>50$ \\
\hline 65 & $\mathrm{Cl}$ & $\mathrm{OH}$ & $2.5 \pm 0.27$ & $4.43 \pm 1.3$ & $1.91 \pm 0.21$ & $1.50 \pm 0.43$ & $22.6 \pm 2.3$ \\
\hline 66 & $\mathrm{Cl}$ & $\mathrm{OMe}$ & $8.93 \pm 1.4$ & $10.65 \pm 1.1$ & $6.46 \pm 2.7$ & $6.89 \pm 1.95$ & $30.8 \pm 2.9$ \\
\hline 67 & $\mathrm{Cl}$ & 3,4,5-OMe & $12.7 \pm 2.6$ & $9.98 \pm 0.69$ & $5.64 \pm 0.56$ & $17.8 \pm 3.6$ & $46.6 \pm 5.2$ \\
\hline 68 & $\mathrm{OMe}$ & $\mathrm{Cl}$ & $4.76 \pm 0.57$ & $3.89 \pm 0.33$ & $2.97 \pm 0.26$ & $8.86 \pm 0.3$ & $20.9 \pm 1.5$ \\
\hline 69 & $\mathrm{OMe}$ & $\mathrm{CF}_{3}$ & $9.87 \pm 0.31$ & $>50$ & $>50$ & $>50$ & $>50$ \\
\hline 70 & OMe & $\mathrm{OH}$ & $2.46 \pm 0.57$ & $1.98 \pm 0.16$ & $2.77 \pm 0.24$ & $3.73 \pm 0.66$ & $34.6 \pm 2.5$ \\
\hline 71 & $\mathrm{OMe}$ & $\mathrm{OMe}$ & $8.76 \pm 0.98$ & $13.4 \pm 1.7$ & $6.78 \pm 3.4$ & $>50$ & $>50$ \\
\hline 72 & $\mathrm{OMe}$ & 3,4,5-OMe & $14.6 \pm 1.7$ & $18.9 \pm 2.3$ & $11.2 \pm 1.65$ & $>50$ & $>50$ \\
\hline 73 & 3,4,5-OMe & $\mathrm{Cl}$ & $7.68 \pm 0.92$ & $11.2 \pm 1.43$ & $8.67 \pm 0.75$ & $3.21 \pm 0.36$ & $30.2 \pm 2.8$ \\
\hline 74 & $3,4,5-\mathrm{OMe}$ & $\mathrm{CF}_{3}$ & $>50$ & $>50$ & $>50$ & $>50$ & $>50$ \\
\hline 75 & 3,4,5-OMe & $\mathrm{OH}$ & $2.5 \pm 0.09$ & $4.6 \pm 0.78$ & $3.16 \pm 0.92$ & $1.8 \pm 0.57$ & $17.6 \pm 1.1$ \\
\hline 76 & 3,4,5-OMe & $\mathrm{OMe}$ & $5.78 \pm 1.9$ & $9.6 \pm 1.7$ & $4.78 \pm 0.41$ & $12.8 \pm 2.3$ & $>50$ \\
\hline 77 & 3,4,5-OMe & 3,4,5-OMe & $8.4 \pm 2.63$ & $14.1 \pm 1.94$ & $7.98 \pm 1.78$ & $5.1 \pm 0.93$ & $20.9 \pm 1.5$ \\
\hline
\end{tabular}

Sreelatha et al. studied a series of novel naphthoquinone amide derivatives for anticancer activity against HeLa and SAS cancer cell lines [52]. Among the analogues synthesised (Figure 23), compounds with a methoxy substituent at C-2 of the quinone ring, such as $\mathbf{7 9} \mathbf{a}$ and $\mathbf{7 9} \mathbf{b}$, were active (Table 21).

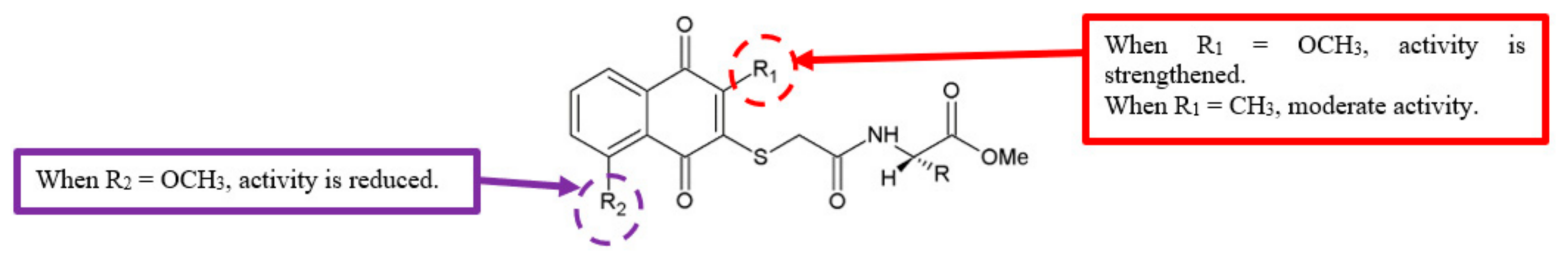

Figure 23. SAR study of naphthoquinone amide derivatives.

Table 21. SAR study of naphthoquinone amide derivatives.

\begin{tabular}{|c|c|c|c|c|c|}
\hline \multirow{2}{*}{ Compounds } & \multirow{2}{*}{$\mathbf{R}$} & \multirow{2}{*}{$\mathbf{R}_{\mathbf{1}}$} & \multirow{2}{*}{$\mathbf{R}_{\mathbf{2}}$} & \multicolumn{2}{|c|}{ Anti-Proliferation Activity $\left(\mathrm{IC}_{50}, \mu \mathrm{M}\right)$} \\
\hline & & & & HeLa & SAS \\
\hline $78 a$ & $\mathrm{CH}_{2} \mathrm{Ph}$ & $\mathrm{CH}_{3}$ & $\mathrm{OCH}_{3}$ & $>100$ & 56.5 \\
\hline $78 b$ & $\mathrm{CH}_{2} \cdot \mathrm{CH}\left(\mathrm{CH}_{3}\right)_{2}$ & $\mathrm{CH}_{3}$ & $\mathrm{OCH}_{3}$ & $>100$ & 78.5 \\
\hline $79 a$ & $\mathrm{H}$ & $\mathrm{OCH}_{3}$ & $\mathrm{H}$ & 77.5 & 12.0 \\
\hline $79 b$ & $\mathrm{CH}_{3}$ & $\mathrm{OCH}_{3}$ & $\mathrm{H}$ & 39.0 & 14.0 \\
\hline $79 c$ & $\mathrm{CH}\left(\mathrm{CH}_{3}\right)_{2}$ & $\mathrm{CH}_{3}$ & $\mathrm{H}$ & 20.0 & 16.0 \\
\hline
\end{tabular}

In contrast, the attachment of the methoxy group at the C-5 position reduced the antiproliferation activity of analogues $\mathbf{7 8} \mathbf{a}$ and $\mathbf{7 8 b}$. Similar results were observed in our study on the anticancer activity of $1^{\prime} S-1^{\prime}$-acetoxychavicol acetate (ACA) analogues on the MDA-MB-231 breast cancer cell line (Figure 24). The analogue 1'-acetoxy-3,5-dimethoxychavicol acetate with a methoxy group at the 
C-5 position showed significantly less activity compared to another analogue without the substituent, 1'-acetoxyeugenol acetate (Table 22) [53]. As such, not only is the methoxy group essential for anticancer activity, but the position of this group is also imperative in the effectiveness of the compound to inhibit the growth of cancer cells.
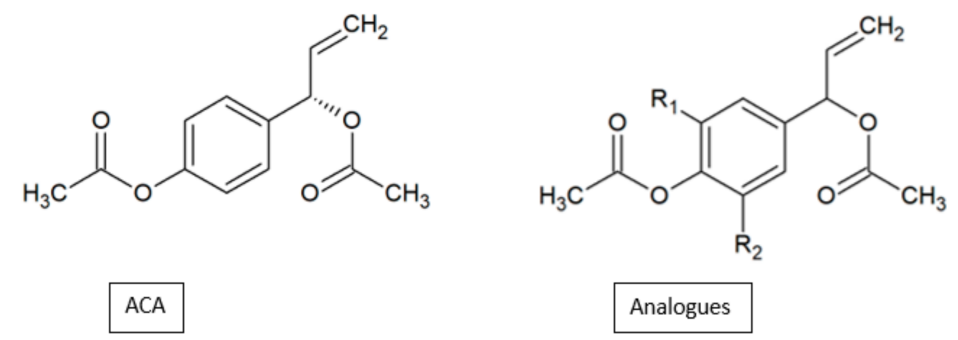

Figure 24. SAR study of 1'S-1'-acetoxychavicol acetate (ACA) derivatives.

Table 22. SAR study of 1'S-1'-acetoxychavicol acetate (ACA) derivatives.

\begin{tabular}{cccc}
\hline Compounds & $\mathbf{R}_{\mathbf{1}}$ & $\mathbf{R}_{\mathbf{2}}$ & $\begin{array}{c}\text { Anti-Proliferation } \\
\text { Activity }\left(\mathrm{IC}_{\mathbf{5 0}}, \boldsymbol{\mu M}\right)\end{array}$ \\
\hline ACA & - & - & $4.8 \pm 0.4$ \\
AEA & - & $\mathrm{OCH}_{3}$ & $9.5 \pm 0.3$ \\
AMCA & $\mathrm{OCH}_{3}$ & $\mathrm{OCH}_{3}$ & $29.6 \pm 5.6$ \\
\hline
\end{tabular}

\subsection{Fluoro (F) Group}

All of the synthesised 1,3,4-oxadiazole analogues were examined for anticancer activity against MCF-7 and HT29 cell lines [12]. It was noticeable that the fluorinated compound $\mathbf{6}$ showed the best activity against MCF-7 cells with an $\mathrm{IC}_{50}$ value of $5.68 \mu \mathrm{g} / \mathrm{mL}$ (Table 2), compared to the reference drug cisplatin with an $\mathrm{IC}_{50}$ value of $11.20 \mu \mathrm{g} / \mathrm{mL}$. Besides, compound 6 also displayed better activity than the other analogues against HT29 cell with an $\mathrm{IC}_{50}$ value of $10.21 \mu \mathrm{g} / \mathrm{mL}$. The SAR analysis illustrated that the fluoro group had the highest antiproliferation potency compared to other substituents.

Zhou and coworkers designed, synthesised and evaluated the 6,7-disubstituted-4-phenoxyquinoline derivatives for in vitro cytotoxicity against various human cancer cell lines such as non-small cell lung cancer (A549), lung (H460), colorectal (HT-29), gastric (MKN-45), and glioblastoma (U87MG) (Figure 25) [54]. The introduction of an electron-withdrawing group, such as a fluoro group, to the analogue $\mathbf{8 1}$ led to an obvious improvement in anticancer activity (Table 23). Analogues 80, 82 and $\mathbf{8 3}$ with at least one fluorine atom showed low $\mathrm{IC}_{50}$ values, indicating that the fluorine atom was necessary to improve the antiproliferation activity.
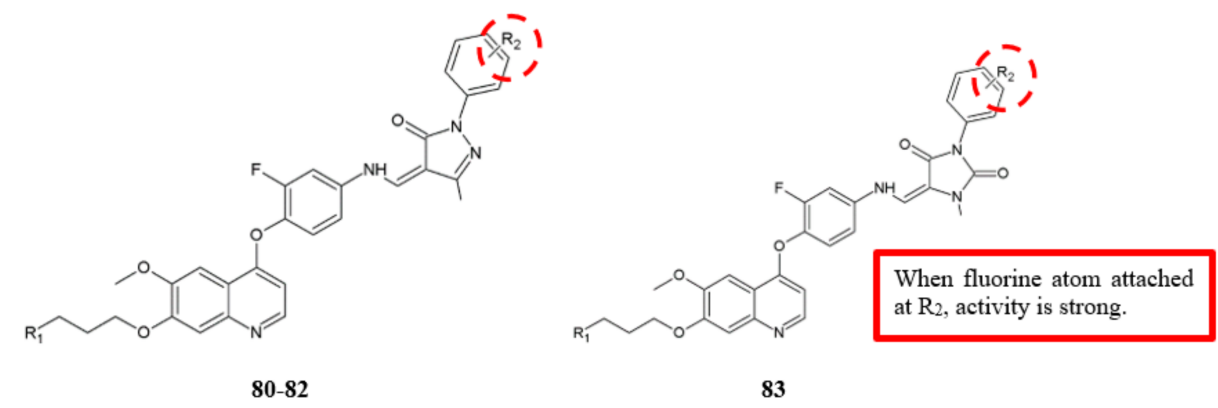

83

Figure 25. SAR study of 6,7-disubstituted-4-phenoxyquinoline derivatives. 
Table 23. SAR study of 6,7-disubstituted-4-phenoxyquinoline derivatives.

\begin{tabular}{|c|c|c|c|c|c|c|c|}
\hline \multirow{2}{*}{ Compounds } & \multirow{2}{*}{$\mathbf{R}_{\mathbf{1}}$} & \multirow{2}{*}{$\mathbf{R}_{2}$} & \multicolumn{5}{|c|}{ Anti-proliferation activity $\left(\mathrm{IC}_{50}, \mu \mathrm{Mol} / \mathrm{L}\right)$} \\
\hline & & & HT-29 & H460 & A549 & MKN-45 & U87MG \\
\hline 80 & & $2-\mathrm{CF}_{3}$ & $0.15 \pm 0.01$ & $0.18 \pm 0.01$ & $0.13 \pm 0.01$ & $0.09 \pm 0.02$ & $1.12 \pm 0.02$ \\
\hline 81 & & $4-\mathrm{F}$ & $0.16 \pm 0.02$ & $0.20 \pm 0.03$ & $0.14 \pm 0.04$ & $0.33 \pm 0.01$ & $1.90 \pm 0.21$ \\
\hline 82 & & $2-\mathrm{CF}_{3}$ & $0.15 \pm 0.02$ & $0.19 \pm 0.02$ & $0.33 \pm 0.03$ & $0.08 \pm 0.003$ & $1.23 \pm 0.01$ \\
\hline 83 & & $2-\mathrm{F}$ & $0.17 \pm 0.04$ & $0.19 \pm 0.03$ & $0.12 \pm 0.02$ & $0.09 \pm 0.01$ & $1.30 \pm 0.02$ \\
\hline
\end{tabular}

\subsection{Methyl $\left(\mathrm{CH}_{3}\right)$ Group}

Newly synthesised naphthoquinone amide analogues were evaluated for their antiproliferation activity against HeLa and SAS cancer cell lines [52]. The introduction of methyl substituent at C-2 of the quinone ring of $79 \mathrm{c}$ proved to be moderately effective for the antiproliferation activity (Table 21).

In 2011, Zhang et al. evaluated the antiproliferation activity of a series of chalcone-type thiosemicarbazide analogues (Figure 26) [55]. Compound 84e with a para methyl group in the B-ring exhibited the highest antiproliferation activity against HepG2 cells (Table 24). This demonstrated that the methyl group contributed to the potent anticancer activity.

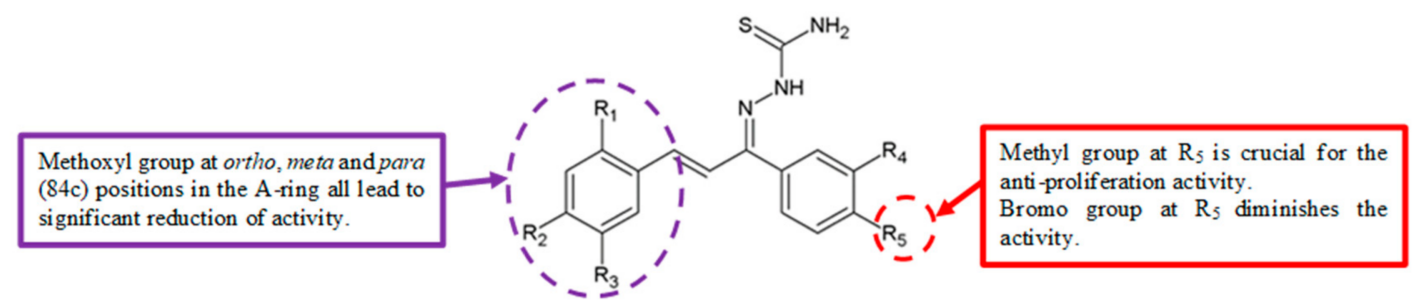

Figure 26. SAR study of chalcone thiosemicarbazide derivatives.

Table 24. SAR study of chalcone thiosemicarbazide derivatives.

\begin{tabular}{ccccccc}
\hline \multirow{2}{*}{ Compounds } & $\mathbf{R}_{\mathbf{1}}$ & $\mathbf{R}_{\mathbf{2}}$ & $\mathbf{R}_{\mathbf{3}}$ & $\mathbf{R}_{\mathbf{4}}$ & $\mathbf{R}_{\mathbf{5}}$ & ${\text { Anti-Proliferation Activity }\left(\mathrm{IC}_{\mathbf{5 0}}, \boldsymbol{\mu M}\right)}^{\text {HepG2 }}$ \\
\hline $\mathbf{8 4 a}$ & $\mathrm{OMe}$ & $\mathrm{H}$ & $\mathrm{H}$ & $\mathrm{H}$ & $\mathrm{H}$ & $20 \pm 3$ \\
$\mathbf{8 4 b}$ & $\mathrm{H}$ & $\mathrm{H}$ & $\mathrm{OMe}$ & $\mathrm{H}$ & $\mathrm{H}$ & $5.53 \pm 0.3$ \\
$\mathbf{8 4} \mathrm{c}$ & $\mathrm{H}$ & $\mathrm{OMe}$ & $\mathrm{H}$ & $\mathrm{H}$ & $\mathrm{H}$ & $10 \pm 2$ \\
$\mathbf{8 4 d}$ & $\mathrm{H}$ & $\mathrm{H}$ & $\mathrm{H}$ & $\mathrm{H}$ & $\mathrm{Br}$ & $6.35 \pm 0.34$ \\
$\mathbf{8 4 e}$ & $\mathrm{H}$ & $\mathrm{H}$ & $\mathrm{H}$ & $\mathrm{H}$ & $\mathrm{Me}$ & $0.78 \pm 0.05$ \\
\hline
\end{tabular}

\subsection{Hydroxy (OH) Group}

In 2016, (Z)-1-(1,3-diphenyl-1H-pyrazol-4-yl)-3-(phenylamino)prop-2-en-1-one derivatives were synthesised and analysed for anticancer effects against HT-29, PC-3, A549 and U87MG human cancer cell lines [51]. SAR analysis showed that hydroxy group, a strong electron-donating group, enhanced the activity of analogues $55,60,65,70$, and 75 (Table 20) when substituted on the aromatic B ring, with $\mathrm{IC}_{50}$ values of $1.35-3.21 \mu \mathrm{M}$. 


\subsection{Ethoxy $\left(\mathrm{CH}_{3} \mathrm{CH}_{2} \mathrm{O}\right)$ Group}

A series of novel (-)-arctigenin analogues were synthesised and tested against human pancreatic cancer cell line PANC-1 for cytotoxicity (Figure 27) [56]. Among the (-)-arctigenin analogues, monoethoxy analogue $86 \mathrm{~b}$ displayed the most preferential cytotoxicity $\left(\mathrm{PC}_{50}\right)=0.49 \mathrm{mM}$, followed by diethoxy analogue $86 a\left(\mathrm{PC}_{50}=0.66 \mathrm{mM}\right)$, and triethoxy analogue $86 \mathrm{c}\left(\mathrm{PC}_{50}=0.78 \mathrm{mM}\right)$. In terms of potency, these compounds were either similar or more effective compared to (-)-arctigenin (85) $\left(\mathrm{PC}_{50}=0.80 \mathrm{mM}\right)$ (Table 25). Thus, the introduction of the ethoxy group to the parent compound improved the cytotoxicity effect.

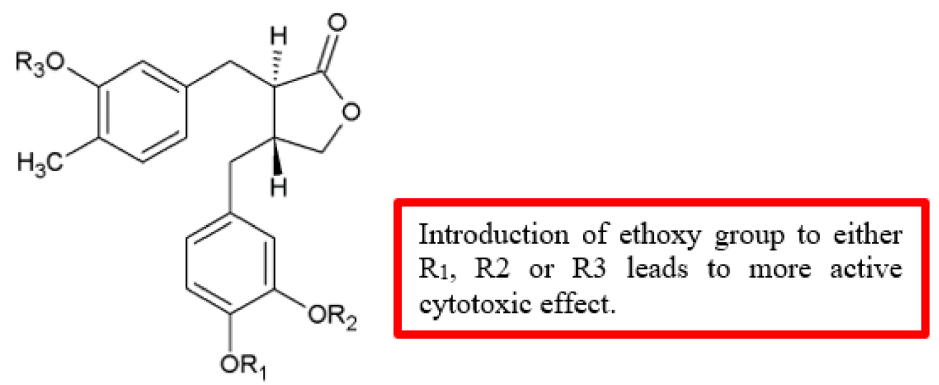

Figure 27. SAR study of (-)-arctigenin derivatives.

Table 25. SAR study of (-)-arctigenin derivatives.

\begin{tabular}{ccccc}
\hline Compounds & $\mathbf{R}_{\mathbf{1}}$ & $\mathbf{R}_{\mathbf{2}}$ & $\mathbf{R}_{\mathbf{3}}$ & Preferential Cytotoxicity $_{\left(\mathbf{P C}_{\mathbf{5 0}}, \boldsymbol{\mu M}\right)}$ \\
\hline Arctigenin, 85 & $\mathrm{Me}$ & $\mathrm{Me}$ & $\mathrm{Me}$ & 0.80 \\
$\mathbf{8 6 a}$ & $\mathrm{Me}$ & $\mathrm{Et}$ & $\mathrm{Et}$ & 0.66 \\
$\mathbf{8 6 b}$ & $\mathrm{Et}$ & $\mathrm{Me}$ & $\mathrm{Me}$ & 0.49 \\
$\mathbf{8 6 c}$ & $\mathrm{Et}$ & $\mathrm{Et}$ & $\mathrm{Et}$ & 0.78 \\
\hline
\end{tabular}

\subsection{Carbonyl $(\mathrm{C}=\mathrm{O})$ Group}

Gonçalves et al. tested the synthesised fluorinated asiatic acid analogues for antiproliferation activity against HeLa and HT-29 cell lines (Figure 28) [57]. Among the analogues, compounds 90-97 that had the pentameric A-ring with an $\alpha, \beta$-unsaturated carbonyl showed significantly higher efficacy compared to the original asiatic acid 87 (Table 26). Also, the compounds exhibited lower $\mathrm{IC}_{50}$ values on HeLa cell line compared to the reference drug cisplatin. The findings are in accordance with previous results that proposed the introduction of $\alpha, \beta$-unsaturated carbonyl moiety in A-ring of some triterpenes boosts the antiproliferation activity [58]. Furthermore, the significance of $\alpha, \beta$-unsaturated carbonyl was subsequently proven by the reduced antiproliferation effect upon the conversion of analogue $\mathbf{9 0}$ into the nitrile analogue $\mathbf{9 8 .}$ 
Hydroxy group in A ring reduces anti-

proliferation activity.

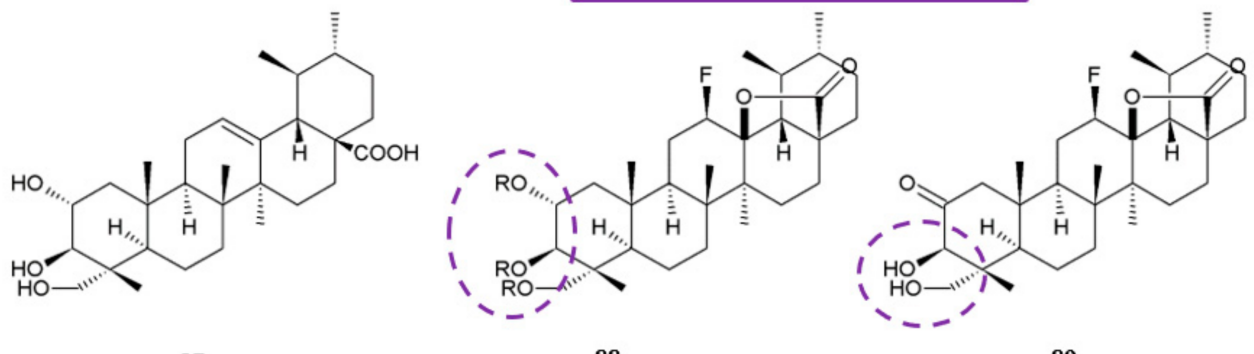

87

88

89

$\alpha, \beta$-unsaturated carbonyl is important for anti-proliferation activity.

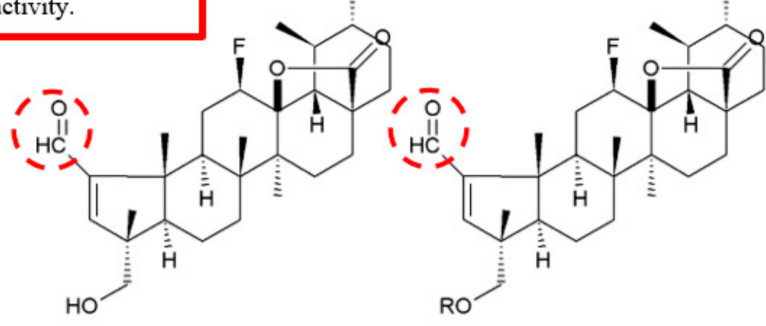

90

91-97

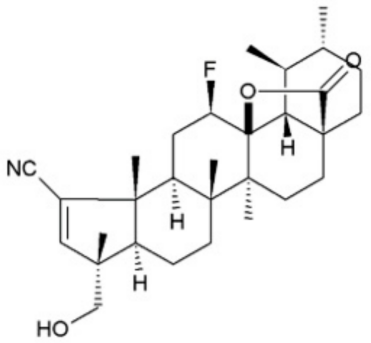

98

Figure 28. SAR study of asiatic acid derivatives.

Table 26. SAR study of asiatic acid derivatives.

\begin{tabular}{|c|c|c|c|}
\hline \multirow{2}{*}{ Compounds } & \multirow{2}{*}{$\mathbf{R}$} & \multicolumn{2}{|c|}{ Anti-Proliferation Activity $\left(\mathrm{IC}_{50}, \mu \mathrm{M}\right)$} \\
\hline & & HT-29 & HeLa \\
\hline Asiatic acid, 87 & - & $64.30 \pm 3.21$ & $52.47 \pm 0.06$ \\
\hline 88 & $\mathrm{H}$ & $51.25 \pm 1.77$ & $60.17 \pm 2.75$ \\
\hline 89 & - & $23.50 \pm 0.71$ & $24.50 \pm 1.41$ \\
\hline 90 & - & $1.28 \pm 0.08$ & $1.08 \pm 0.04$ \\
\hline 91 & & $2.02 \pm 0.19$ & $1.40 \pm 0.14$ \\
\hline 92 & & $1.29 \pm 0.09$ & $0.95 \pm 0.01$ \\
\hline 93 & & $1.05 \pm 0.05$ & $0.80 \pm 0.04$ \\
\hline 94 & & $6.35 \pm 0.64$ & $3.48 \pm 0.04$ \\
\hline
\end{tabular}


Table 26. Cont.

\begin{tabular}{|c|c|c|c|}
\hline \multirow{2}{*}{ Compounds } & \multirow{2}{*}{$\mathbf{R}$} & \multicolumn{2}{|c|}{ Anti-Proliferation Activity $\left(\mathrm{IC}_{50}, \mu \mathrm{M}\right)$} \\
\hline & & HT-29 & HeLa \\
\hline 95 & & $0.71 \pm 0.02$ & $0.67 \pm 0.07$ \\
\hline 96 & & $2.37 \pm 0.23$ & $1.62 \pm 0.09$ \\
\hline 97 & & $2.80 \pm 0.14$ & $1.63 \pm 0.15$ \\
\hline 98 & - & N.D. & $7.50 \pm 0.42$ \\
\hline Cisplatin & - & N.D. & $2.28 \pm 0.26$ \\
\hline
\end{tabular}

\section{Weak Functional Groups, Their Position and Antiproliferation Effect}

\subsection{Methoxy $\left(\mathrm{OCH}_{3}\right)$ Group}

To obtain data on the SAR in the imidazobenzothiazole series, Trapani et al. [48] examined several analogues for their cytotoxic effects. Introduction of electron-donating substituents such as methoxy group at C-7 position gave better activity compared to their parent compound. However, additional substitution of methoxy groups at the 5- and 8- positions (analogues 47 and 49) caused the reduction of cytotoxic activity compared to the mono-methoxy analogue 46 (Table 17). Hence, the more methoxy groups are substituted to the compound, the less efficient is its ability to inhibit the growth of cancer cells.

Structure-activity relationships in the thiosemicarbazide derivatives synthesised by Zhang et al. [55] demonstrated that the analogues with changes to the methoxy group at ortho (84a), meta (84b) and para (84c) positions in the A-ring led to a remarkably reduced cytotoxic effect (Table 24).

\subsection{Bromo (Br) Group}

Freitas et al. carried out a study and presented the effects of 8-hydroxyquinoline analogues on antiproliferation activity [50]. The brominated analogue $\mathbf{5 2 d}$ showed weak cytotoxic effects with the $\log$ of molar concentration that inhibits $50 \%$ net cell growth $\left(\mathrm{GI}_{50}\right)$ mean graph midpoint (MG MID) value $=1.3$ (Table 19). In short, the bromo group attached to the compounds reduced the potency of antiproliferation.

In the Zhang et al. study, thiosemicarbazide analogues with halogen substitution at the para position in the B-ring mostly showed good antiproliferation activity [55]. However, analogue $\mathbf{8 4 d}$ with a bromo substituent at the para position of the B-ring exhibited low activity (Table 24).

\subsection{Methyl $\left(\mathrm{CH}_{3}\right)$ Group}

Substitution of a methyl group at the benzene ring of 1,3,4-oxadiazole derivatives gave rise to low antiproliferation activity [12]. It is depicted clearly in Table 2, as the methylated analogues 7, 9 and $\mathbf{1 1}$ had higher $\mathrm{IC}_{50}$ values than other analogues, which is in the range of $18.89-42.30 \mu \mathrm{g} / \mathrm{mL}$. Hence, the methyl group is an unfavourable substituent in terms of anticancer activity. 


\subsection{Fluoro (F) Group}

Compound $\mathbf{5 2 b}$ in a series of 8-hydroxyquinoline derivatives [50] did not exhibit significant cytotoxicity due to the substitution of fluorine atom at the 4-position (Table 19). Hence, fluoro groups may not be a good choice for attachment to compounds for inhibiting cancer cell growth.

\subsection{Iodo (I) Group}

The analogue of 8-hydroxyquinoline 52a with an iodine atom at the 4-position showed a low cytotoxic effect when compared to other halogen substituents [50] (Table 19). Iodine is considered a weak electronegative atom and might not increase the lipophilicity and hence will lower the antiproliferation activity of the compound.

\subsection{Chloro (Cl) Group}

Reddy and colleagues studied the antiproliferation effects of (Z)-1-(1,3-diphenyl-1H-pyrazol-4-yl)-3-(phenylamino)prop-2-en-1-one derivatives against various cancer cell lines [51]. The data showed that analogues 53, 58, 63, 68 and 73 with an electron-withdrawing chloro substitution on the B ring exhibited low cytotoxic activity on the cancer cells (Table 20).

\subsection{Trifluoromethyl $\left(\mathrm{CF}_{3}\right)$ Group}

From the SAR study of (Z)-1-(1,3-diphenyl-1H-pyrazol-4-yl)-3-(phenylamino)prop-2-en-1-one derivatives against different cancer cells [51], analogues 54, 59, 64, 69, and 74 with a trifluoromethyl group substituted on the B ring showed weak cytotoxic effects (Table 21). This indicated that the trifluoromethyl group is not important for antiproliferation activity.

\subsection{Hydroxy $(\mathrm{OH})$ Group}

Evaluation of the SAR of novel fluorinated asiatic acid analogues was carried out based on their antiproliferation effect against HeLa and HT-29 cell lines [57]. As shown in Table 26, compound 88 with three free hydroxyl groups in the A-ring exhibited lower antiproliferation activity when compared with compound $\mathbf{8 9}$ which had two free hydroxyl groups. However, when the two hydroxyl groups in compound 89 were acetylated, the activity increased. These results indicated that free hydroxyl groups in A-ring are not important for the antiproliferation effect.

\section{Conclusions}

Discovery and development of anticancer agents that can inhibit metastasis is an important agenda in cancer therapy. As such, structural modifications of potential anticancer compounds can elucidate the functions of substitutions in mediating antimigration and antiproliferation effects. SAR analysis developed by different research teams is summarised in Table 27. Among the functional groups, most of the electron-withdrawing groups such as fluoro, chloro, nitro, amino, and carbonyl groups showed stronger activity than those with electron-donating groups such as methyl and methoxy groups. Although some studies showed that electron-donating groups performed well in anticancer activity while electron-withdrawing groups exhibited weak activity, this could be due to the influence of steric hindrance. Moreover, in terms of position of substituents, para substitution displayed better inhibition of both migration and growth of cancer cells. Overall, there is still a lot to explore in terms of the effects of different functional groups and their positions toward anticancer activity. With this in consideration, further investigation can be carried out to develop better anticancer drugs with improved antimetastatic activity. 
Table 27. Summary of the antimigration and antiproliferation effects of different substituents.

\begin{tabular}{|c|c|c|c|}
\hline \multicolumn{4}{|c|}{ Effective Functional Groups for Antimigration Effect } \\
\hline Functional Groups & Analogues of & Reference & Figure \\
\hline \multirow{4}{*}{ Fluoro } & Isocoumarin & [9] & Figure 1 \\
\hline & Brartemicin & [10] & Figure 2 \\
\hline & 1,3,4-oxadiazole & [12] & Figure 3 \\
\hline & Benzoylbenzophenone thiosemicarbazone & [15] & Figure 4 \\
\hline \multirow{4}{*}{ Methoxy } & 4-anilino-quinazoline & [23] & Figure 5 \\
\hline & 2-furanylvinylquinoline & [24] & Figure 6 \\
\hline & 4-methyl-2-(4-pyridinyl)thiazole-5-carboxamide & [27] & Figure 7 \\
\hline & EF24 & [28] & Figure 8 \\
\hline \multirow{3}{*}{ Methyl } & BU-4664L & [29] & Figure 9 \\
\hline & Isomalyngamide $\mathrm{A}$ & [31] & Figure 10 \\
\hline & Diarylamino-1,3,5-triazine & [32] & Figure 11 \\
\hline \multirow{3}{*}{ Amino } & 4-anilino-quinazoline & [23] & Figure 5 \\
\hline & Triarylethylene & [33] & Figure 12 \\
\hline & Benzamide Ilomastat & [38] & Figure 13 \\
\hline Hydroxy & Brartemicin & [10] & Figure 2 \\
\hline Nitro & 4-methyl-2-(4-pyridinyl)thiazole-5-carboxamide & [27] & Figure 7 \\
\hline Bromo & 2,3-diaryl-4-thiazolidinone & [39] & Figure 14 \\
\hline Chloro & Benzyloxyphenylmethylaminophenol & [44] & Figure 15 \\
\hline \multicolumn{4}{|c|}{ Weak Functional Groups for Antimigration Effect } \\
\hline Functional Groups & Analogues of & Reference & Figure \\
\hline \multirow{3}{*}{ Methoxy } & Brartemicin & [10] & Figure 2 \\
\hline & Benzoylbenzophenone thiosemicarbazone & [15] & Figure 4 \\
\hline & Curcumin & [45] & Figure 16 \\
\hline \multirow{3}{*}{ Methyl } & Brartemicin & [10] & Figure 2 \\
\hline & 1,3,4-oxadiazole & [12] & Figure 3 \\
\hline & Sipholenol A & [46] & Figure 17 \\
\hline \multirow{2}{*}{ Hydroxy } & Benzoylbenzophenone thiosemicarbazone & [15] & Figure 4 \\
\hline & Andrographolide & [47] & Figure 18 \\
\hline Bromo & Benzoylbenzophenone thiosemicarbazone & [15] & Figure 4 \\
\hline Chloro & 4-methyl-2-(4-pyridinyl)thiazole-5-carboxamide & [27] & Figure 7 \\
\hline Methylamino & Diarylamino-1,3,5-triazine & [32] & Figure 11 \\
\hline \multicolumn{4}{|c|}{ Effective Functional Groups for Antiproliferation Effect } \\
\hline Functional Groups & Analogues of & Reference & Figure \\
\hline \multirow{3}{*}{ Chloro } & Imidazobenzothiazole & [48] & Figure 19 \\
\hline & Purine & [49] & Figure 20 \\
\hline & 8-hydroxyquinoline & [50] & Figure 21 \\
\hline \multirow[t]{2}{*}{ Methoxy } & (Z)-1-(1,3-diphenyl-1H-pyrazol-4-yl)-3-(phenylamino)prop-2-en-1-one & [51] & Figure 22 \\
\hline & Naphthoquinone amide & [52] & Figure 23 \\
\hline \multirow{2}{*}{ Fluoro } & 1,3,4-oxadiazole & [12] & Figure 3 \\
\hline & 6,7-disubstituted-4-phenoxyquinoline & [54] & Figure 24 \\
\hline \multirow[t]{2}{*}{ Methyl } & Naphthoquinone amide & [52] & Figure 2 \\
\hline & Thiosemicarbazide & [55] & Figure 25 \\
\hline Hydroxy & (Z)-1-(1,3-diphenyl-1H-pyrazol-4-yl)-3-(phenylamino)prop-2-en-1-one & [51] & Figure 22 \\
\hline Ethoxy & $(-)$-arctigenin & [56] & Figure 26 \\
\hline Carbonyl & Fluorinated asiatic acid & [57] & Figure 27 \\
\hline
\end{tabular}


Table 27. Cont.

\begin{tabular}{cccc}
\hline \multirow{2}{*}{ Functional Groups } & Weak Functional Groups for Antiproliferation Effect & & \\
\hline \multirow{2}{*}{ Methoxy } & Analogues of & Reference & Figure \\
\cline { 2 - 4 } & Imidazobenzothiazole & {$[48]$} & Figure 19 \\
\hline \multirow{2}{*}{ Bromo } & Thiosemicarbazide & {$[55]$} & Figure 25 \\
\cline { 2 - 4 } & 8-hydroxyquinoline & {$[50]$} & Figure 21 \\
\hline Methyl & Thiosemicarbazide & {$[55]$} & Figure 25 \\
\hline Fluoro & 1,3,4-oxadiazole & {$[12]$} & Figure 3 \\
\hline Iodo & 8-hydroxyquinoline & {$[50]$} & Figure 21 \\
\hline Chloro & 8-hydroxyquinoline & {$[50]$} & Figure 21 \\
\hline Trifluoromethyl & (Z)-1-(1,3-diphenyl-1H-pyrazol-4-yl)-3-(phenylamino)prop-2-en-1-one & {$[51]$} & Figure 22 \\
\hline Hydroxy & Fluorinated asiatic acid & {$[57]$} & Figure 27 \\
\hline
\end{tabular}

Author Contributions: Conceptualization, S.K.L.; investigation, S.K.L; writing-S.K.L., S.M., N.H.N.; writing-review and editing, S.M., N.H.N., N.M.A.; visualization, S.K.L., S.M.; supervision, N.H.N.; funding acquisition, N.M.A. All authors have read and agreed to the published version of the manuscript.

Funding: This review was supported by the Centre for Research in Biotechnology for Agriculture (CEBAR) Grant (RU021-2019) and MOHE-Top 100 (TU002E-2018).

Conflicts of Interest: The authors declare no conflict of interest.

\section{References}

1. Torre, L.A.; Bray, F.; Siegel, R.L.; Ferlay, J.; Lortet-Tieulent, J.; Jemal, A. Global Cancer Statistics, 2012. CA Cancer J. Clin. 2015, 65, 87-108. [CrossRef] [PubMed]

2. Butler, M.S. Natural products to drugs: Natural product-derived compounds in clinical trials. Nat. Prod. Rep. 2008, 25, 475. [CrossRef]

3. Guéritte, F.; Fahy, J. Anticancer Agents from Natural Products; CRC Press: Boca Raton, FL, USA, 2005.

4. Cseke, L.J.; Kirakosyan, A.; Kaufmann, P.B.; Warber, S.L.; Duke, J.A.; Brielmann, H.L. Natural Products from Plants, 2nd ed.; CRC, Taylor and Francis: Boca Raton, FL, USA, 2006.

5. Kane, R.C.; Bross, P.F.; Farrell, A.T.; Pazdur, R. Velcade: U.S. FDA approval for the treatment of multiple myeloma progressing on prior therapy. Oncology 2003, 8, 508-513. [CrossRef] [PubMed]

6. Sieber, S.M.; Mead, J.A.; Adamson, R.H. Pharmacology of antitumor agents from higher plants. Cancer Treat. Rep. 1976, 60, 1127-1139. [PubMed]

7. Chaffer, C.L.; Weinberg, R.A. A Perspective on Cancer Cell Metastasis. Science 2011, 331, $1559-1564$. [CrossRef]

8. Steeg, P.S.; Theodorescu, D. Metastasis: A therapeutic target for cancer. Nat. Clin. Pr. Oncol. 2008, 5, $206-219$. [CrossRef]

9. Abid, O.-U.-R.; Khalid, M.; Hussain, M.T.; Hanif, M.; Qadeer, G.; Rama, N.H.; Kornienko, A.; Khan, K.M. Synthesis and anti-cancer, anti-metastatic evaluation of some new fluorinated isocoumarins and 3,4-dihydroisocoumarins. J. Fluor. Chem. 2012, 135, 240-245. [CrossRef]

10. Jiang, Y.-L.; Tang, L.-Q.; Miyanaga, S.; Igarashi, Y.; Saiki, I.; Liu, Z.-P. Synthesis and evaluation of trehalose-based compounds as anti-invasive agents. Bioorgan. Med. Chem. Lett. 2011, 21, 1089-1091. [CrossRef]

11. Hiscox, S.; Barnfather, P.; Hayes, E.; Bramble, P.; Christensen, J.; Nicholson, R.I.; Barrett-Lee, P. Inhibition of Focal Adhesion Kinase Suppresses the Adverse Phenotype of Endocrine-Resistant Breast Cancer Cells and Improves Endocrine Response in Endocrine-Sensitive Cells. Breast Cancer Res Treat. 2011, 125, 659-669. [CrossRef]

12. Zhang, S.; Luo, Y.; He, L.-Q.; Liu, Z.-J.; Jiang, A.-Q.; Yang, Y.-H.; Zhu, H.-L. Synthesis, biological evaluation, and molecular docking studies of novel 1,3,4-oxadiazole derivatives possessing benzotriazole moiety as FAK inhibitors with anticancer activity. Bioorganic Med. Chem. 2013, 21, 3723-3729. [CrossRef] 
13. Gocheva, V.; Joyce, J.A. Cysteine Cathepsins and the Cutting Edge of Cancer Invasion. Cell Cycle 2007, 6, 60-64. [CrossRef] [PubMed]

14. Lankelma, J.M.; Voorend, D.M.; Barwari, T.; Koetsveld, J.; Van Der Spek, A.H.; De Porto, A.P.; Van Rooijen, G.; Van Noorden, C.J. Cathepsin L, target in cancer treatment? Life Sci. 2010, 86, 225-233. [CrossRef] [PubMed]

15. Parker, E.N.; Song, J.; Kumar, G.D.K.; Odutola, S.O.; Chavarria, G.E.; Charlton-Sevcik, A.K.; Strecker, T.E.; Barnes, A.L.; Sudhan, D.R.; Wittenborn, T.R.; et al. Synthesis and biochemical evaluation of benzoylbenzophenone thiosemicarbazone analogues as potent and selective inhibitors of cathepsin L. Bioorganic Med. Chem. 2015, 23, 6974-6992. [CrossRef] [PubMed]

16. Wieduwilt, M.J.; Moasser, M.M. The epidermal growth factor receptor family: Biology driving targeted therapeutics. Cell. Mol. Life Sci. 2008, 65, 1566-1584. [CrossRef] [PubMed]

17. Yun, C.-H.; Boggon, T.J.; Li, Y.; Woo, M.S.; Greulich, H.; Meyerson, M.; Eck, M.J. Structures of lung cancer-derived EGFR mutants and inhibitor complexes: Mechanism of activation and insights into differential inhibitor sensitivity. Cancer Cell 2007, 11, 217-227. [CrossRef] [PubMed]

18. Högnason, T.; Chatterjee, S.; Vartanian, T.; Ratan, R.R.; Ernewein, K.M.; Habib, A.A. Epidermal growth factor receptor induced apoptosis: Potentiation by inhibition of Ras signaling. FEBS Lett. 2001, 491, 9-15. [CrossRef]

19. Andl, C.D.; Mizushima, T.; Oyama, K.; Bowser, M.; Nakagawa, H.; Rustgi, A.K. EGFR-induced cell migration is mediated predominantly by the JAK-STAT pathway in primary esophageal keratinocytes. Am. J. Physiol. Liver Physiol. 2004, 287, G1227-G1237. [CrossRef]

20. Tabernero, J. The Role of VEGF and EGFR Inhibition: Implications for Combining Anti-VEGF and Anti-EGFR Agents. Mol. Cancer Res. 2007, 5, 203-220. [CrossRef]

21. Arora, A.; Scholar, E.M. Role of Tyrosine Kinase Inhibitors in Cancer Therapy. J. Pharmacol. Exp. Ther. 2005, 315, 971-979. [CrossRef]

22. Ravez, S.; Six, P.; Chavatte, P.; Garofalo, A.; Farce, A.; Lemoine, A.; Goossens, L.; Depreux, P. Synthesis and Structure-Activity Relationships of (Aryloxy)quinazoline Ureas as Novel, Potent, and Selective Vascular Endothelial Growth Factor Receptor-2 Inhibitors. J. Med. Chem. 2012, 55, 1189-1204.

23. Barbosa, M.L.D.C.; Lima, L.M.; Tesch, R.; Sant'Anna, C.M.R.; Totzke, F.; Kubbutat, M.H.; Schächtele, C.; Laufer, S.A.; Barreiro, E.J. Novel 2-chloro-4-anilino-quinazoline derivatives as EGFR and VEGFR-2 dual inhibitors. Eur. J. Med. Chem. 2014, 71, 1-14. [CrossRef]

24. Tseng, C.-H.; Tzeng, C.-C.; Chiu, C.-C.; Hsu, C.-Y.; Chou, C.-K.; Chen, Y.-L. Discovery of 2-[2-(5-nitrofuran-2-yl)vinyl]quinoline derivatives as a novel type of antimetastatic agents. Bioorganic Med. Chem. 2015, 23, 141-148. [CrossRef] [PubMed]

25. Griggs, J.; Skepper, J.N.; Smith, G.A.; Brindle, K.M.; Metcalfe, J.C.; Hesketh, R. Inhibition of Proliferative Retinopathy by the Anti-Vascular Agent Combretastatin-A4. Am. J. Pathol. 2002, 160, 1097-1103. [CrossRef]

26. Longo, N.; Yáñez-Mó, M.; Mittelbrunn, M.; de la Rosa, G.; Muñoz, M.L.; Sánchez-Madrid, F.; Sánchez-Mateos, P. Regulatory Role of Tetraspanin CD9 in Tumor-Endothelial Cell Interaction during Transendothelial Invasion of Melanoma Cells. Blood 2001, 98, 3717-3726. [CrossRef] [PubMed]

27. Zhou, W.; Tang, W.; Sun, Z.; Li, Y.; Dong, Y.; Pei, H.; Peng, Y.; Wang, J.; Shao, T.; Jiang, Z.; et al. Discovery and Optimization of N-Substituted 2-(4-pyridinyl)thiazole carboxamides against Tumor Growth through Regulating Angiogenesis Signaling Pathways. Sci. Rep. 2016, 6, 33434. [CrossRef]

28. Wu, J.; Wu, S.; Shi, L.; Zhang, S.; Ren, J.; Yao, S.; Yun, D.; Huang, L.; Wang, J.; Li, W.; et al. Design, synthesis, and evaluation of asymmetric EF24 analogues as potential anti-cancer agents for lung cancer. Eur. J. Med. Chem. 2017, 125, 1321-1331. [CrossRef]

29. Miyanaga, S.; Sakurai, H.; Saiki, I.; Onaka, H.; Igarashi, Y. Anti-invasive and anti-angiogenic activities of naturally occurring dibenzodiazepine BU-4664L and its derivatives. Bioorganic Med. Chem. Lett. 2010, 20, 963-965. [CrossRef]

30. Gunasekera, S.P.; Owle, C.S.; Montaser, R.; Luesch, H.; Paul, V.J. Malyngamide 3 and cocosamides A and B from the marine cyanobacterium Lyngbya majuscula from Cocos Lagoon, Guam. J. Nat. Prod. 2011, 74, 871-876. [CrossRef]

31. Chang, T.T.; More, S.V.; Lu, I.-H.; Hsu, J.-C.; Chen, T.-J.; Jen, Y.C.; Lu, C.-K.; Li, W.-S. Isomalyngamide A, A-1 and their analogs suppress cancer cell migration in vitro. Eur. J. Med. Chem. 2011, 46, 3810-3819. [CrossRef] 
32. Dao, P.; Jarray, R.; Le Coq, J.; Lietha, D.; Loukaci, A.; Lepelletier, Y.; Hadj-Slimane, R.; Garbay, C.; Raynaud, F.; Chen, H. Synthesis of novel diarylamino-1,3,5-triazine derivatives as FAK inhibitors with anti-angiogenic activity. Bioorganic Med. Chem. Lett. 2013, 23, 4552-4556. [CrossRef]

33. Kaur, G.; Mahajan, M.P.; Pandey, M.K.; Singh, P.; Ramisetti, S.R.; Sharma, A.K. Design, synthesis, and anti-breast cancer evaluation of new triarylethylene analogs bearing short alkyl- and polar amino-/amido-ethyl chains. Bioorganic Med. Chem. Lett. 2016, 26, 1963-1969. [CrossRef] [PubMed]

34. Shay, G.; Lynch, C.C.; Fingleton, B. Moving targets: Emerging roles for MMPs in cancer progression and metastasis. Matrix Boil. 2015, 44, 200-206. [CrossRef] [PubMed]

35. Brown, G.T.; Murray, G.I. Current mechanistic insights into the roles of matrix metalloproteinases in tumour invasion and metastasis. J. Pathol. 2015, 237, 273-281. [CrossRef]

36. Zheng, H.; Takahashi, H.; Murai, Y.; Cui, Z.; Nomoto, K.; Niwa, H.; Tsuneyama, K.; Takano, Y. Expressions of MMP-2, MMP-9 and VEGF are closely linked to growth, invasion, metastasis and angiogenesis of gastric carcinoma. Anticancer. Res. 2006, 26, 3579-3583. [PubMed]

37. Spinale, F.G.; Villarreal, F. Targeting matrix metalloproteinases in heart disease: Lessons from endogenous inhibitors. Biochem. Pharmacol. 2014, 90,7-15. [CrossRef] [PubMed]

38. Song, J.; Peng, P.; Chang, J.; Liu, M.-M.; Yu, J.-M.; Zhou, L.; Sun, X. Selective non-zinc binding MMP-2 inhibitors: Novel benzamide Ilomastat analogs with anti-tumor metastasis. Bioorganic Med. Chem. Lett. 2016, 26, 2174-2178. [CrossRef] [PubMed]

39. Wu, J.; Yu, L.; Yang, F.; Li, J.; Wang, P.; Zhou, W.; Qin, L.; Li, Y.; Luo, J.; Yi, Z.; et al. Optimization of 2-(3-(arylalkyl amino carbonyl) phenyl)-3-(2-methoxyphenyl)-4-thiazolidinone derivatives as potent antitumor growth and metastasis agents. Eur. J. Med. Chem. 2014, 80, 340-351. [CrossRef]

40. Ihle, J.N. The Stat family in cytokine signaling. Curr. Opin. Cell Boil. 2001, 13, 211-217. [CrossRef]

41. Yu, H.; Pardoll, D.; Jove, R. STATs in cancer inflammation and immunity: A leading role for STAT3. Nat. Rev. Cancer 2009, 9, 798-809. [CrossRef]

42. Xie, T.-X.; Wei, D.; Liu, M.; Gao, A.C.; Ali-Osman, F.; Sawaya, R.; Huang, S. Stat3 activation regulates the expression of matrix metalloproteinase-2 and tumor invasion and metastasis. Oncogene 2004, 23, 3550-3560. [CrossRef]

43. Kamran, M.Z.; Gude, R.P. Pentoxifylline inhibits melanoma tumor growth and angiogenesis by targeting STAT3 signaling pathway. Biomed. Pharmacother. 2013, 67, 399-405. [CrossRef] [PubMed]

44. Gao, D.; Xiao, Q.; Zhang, M.; Li, Y. Design, synthesis and biological evaluation of benzyloxyphenyl-methylaminophenol derivatives as STAT3 signaling pathway inhibitors. Bioorganic Med. Chem. 2016, 24, 2549-2558. [CrossRef] [PubMed]

45. Yodkeeree, S.; Chaiwangyen, W.; Garbisa, S.; Limtrakul, P. Curcumin, demethoxycurcumin and bisdemethoxycurcumin differentially inhibit cancer cell invasion through the down-regulation of MMPs and uPA. J. Nutr. Biochem. 2009, 20, 87-95. [CrossRef] [PubMed]

46. Foudah, A.I.; Jain, S.; Busnena, B.A.; El Sayed, K.A.; Jain, D.S.; El Sayed, D.K.A. Optimization of Marine Triterpene Sipholenols as Inhibitors of Breast Cancer Migration and Invasion. ChemMedChem 2013, 8, 497-510. [CrossRef] [PubMed]

47. Wu, Z.-W.; Xu, H.-W.; Dai, G.-F.; Liu, M.-J.; Zhu, L.-P.; Wu, J.; Wang, Y.-N.; Wu, F.-J.; Zhao, D.; Gao, M.-F.; et al. Improved inhibitory activities against tumor-cell migration and invasion by 15-benzylidene substitution derivatives of andrographolide. Bioorganic Med. Chem. Lett. 2013, 23, 6421-6426. [CrossRef] [PubMed]

48. Trapani, G.; Franco, M.; Latrofa, A.; Reho, A.; Liso, G. Synthesis, in vitro and in vivo cytotoxicity, and prediction of the intestinal absorption of substituted 2-ethoxycarbonyl-imidazo[2,1-b]benzothiazoles. Eur. J. Pharm. Sci. 2001, 14, 209-216. [CrossRef]

49. Morales, F.; Ramírez, A.; Conejo-Garcia, A.; Morata, C.; Marchal, J.A.; Campos, J.M. Anti-proliferative activity of 2,6-dichloro-9- or 7-(ethoxycarbonylmethyl)-9H- or 7H-purines against several human solid tumour cell lines. Eur. J. Med. Chem. 2014, 76, 118-124. [CrossRef]

50. Freitas, L.B.D.O.; Borgati, T.F.; De Freitas, R.P.; Ruiz, A.L.; Marchetti, G.M.; De Carvalho, J.E.; Da Cunha, E.F.; Ramalho, T.C.; Alves, R.B. Synthesis and antiproliferative activity of 8-hydroxyquinoline derivatives containing a 1,2,3-triazole moiety. Eur. J. Med. Chem. 2014, 84, 595-604. [CrossRef]

51. Reddy, T.S.; Reddy, V.G.; Kulhari, H.; Shukla, R.; Kamal, A.; Bansal, V. Synthesis of (Z)-1-(1,3-diphenyl-1H-pyrazol-4-yl)-3-(phenylamino)prop-2-en-1-one derivatives as potential anticancer and apoptosis inducing agents. Eur. J. Med. Chem. 2016, 117, 157-166. [CrossRef] 
52. Sreelatha, T.; Kandhasamy, S.; Dinesh, R.; Shruthy, S.; Shweta, S.; Mukesh, D.; Karunagaran, D.; Balaji, R.; Mathivanan, N.; Perumal, P.T. Synthesis and SAR study of novel anticancer and antimicrobial naphthoquinone amide derivatives. Bioorganic Med. Chem. Lett. 2014, 24, 3647-3651. [CrossRef]

53. Liew, S.K.; Azmi, M.N.; La In, L.; Awang, K.; Nagoor, N.H. Anti-proliferative, apoptotic induction, and anti-migration effects of hemi-synthetic 1'S-1'-acetoxychavicol acetate analogs on MDA-MB-231 breast cancer cells. Drug Des. Dev. Ther. 2017, 11, 2763-2776. [CrossRef]

54. Zhou, S.; Ren, J.; Liu, M.; Ren, L.; Liu, Y.; Gong, P. Design, synthesis and pharmacological evaluation of 6,7-disubstituted-4-phenoxyquinoline derivatives as potential antitumor agents. Bioorganic Chem. 2014, 57, 30-42. [CrossRef] [PubMed]

55. Zhang, H.-J.; Qian, Y.; Zhu, D.-D.; Yang, X.-G.; Zhu, H.-L. Synthesis, molecular modeling and biological evaluation of chalcone thiosemicarbazide derivatives as novel anticancer agents. Eur. J. Med. Chem. 2011, 46, 4702-4708. [CrossRef] [PubMed]

56. Kudou, N.; Taniguchi, A.; Sugimoto, K.; Matsuya, Y.; Kawasaki, M.; Toyooka, N.; Miyoshi, C.; Awale, S.; Dibwe, D.F.; Esumi, H.; et al. Synthesis and antitumor evaluation of arctigenin derivatives based on antiausterity strategy. Eur. J. Med. Chem. 2013, 60, 76-88. [CrossRef] [PubMed]

57. Gonçalves, B.M.; Salvador, J.A.R.; Marín, S.; Cascante, M. Synthesis and anticancer activity of novel fluorinated asiatic acid derivatives. Eur. J. Med. Chem. 2016, 114, 101-117. [CrossRef]

58. Sporn, M.B.; Liby, K.T.; Yore, M.M.; Fu, L.; Lopchuk, J.M.; Gribble, G.W. New Synthetic Triterpenoids: Potent Agents for Prevention and Treatment of Tissue Injury Caused by Inflammatory and Oxidative Stress. J. Nat. Prod. 2011, 74, 537-545. [CrossRef] [PubMed]

(C) 2020 by the authors. Licensee MDPI, Basel, Switzerland. This article is an open access article distributed under the terms and conditions of the Creative Commons Attribution (CC BY) license (http://creativecommons.org/licenses/by/4.0/). 